\title{
FROM THE PERIPHERY TO THE CENTER OF GLOBAL KNOWLEDGE PRODUCTION? A BIBLIOMETRIC ANALYSIS OF THE EVOLUTION OF A SOCIAL SCIENCE COMMUNITY FROM A SMALL COUNTRY: AUSTRIA
}

\author{
Arno Tausch \\ Innsbruck University \\ Corvinus University Budapest
}

This bibliometric analysis of the global presence of Austrian political science (104 senior political scientists) is based on Scopus and OCLC Worldcat. Our global market presence indicators are: the number of articles indexed in Scopus; the total number of quotations documented in Scopus; the H-Index according to Scopus; OCLC Worldcat: book with the largest global library presence; OCLC Worldcat: book with the second largest global library presence; OCLC Worldcat: book with the third largest global library presence. We also presented the results of a promax factor analysis of our data. We provide rankings of the global presence of Austrian political science according to the criteria used in this article. There is ample evidence of a successful publication strategy based on the international journals, indexed in Scopus and the diffusion of book titles in the global libraries, contained in the OCLC Worldcat by a significant proportion of the Austrian political science community. We introduce some measures of comparison of their performance with the German, Swiss, and American political science communities. Data from the Clarivate Analytics Web of Knowledge support our contentions, also over the time period of 1970-2019.

Arguments against an international publication strategy, citing the global science enterprise as an international mode of power, are utterly wrong. We show that the relationship of the often invoked 'critical' political science and 'mainstream publishing' can be a positive one, discussing the example of current political transformations in Portugal, one of the few cases of a successful political left-wing project in Europe. There is no alternative to mainstream scientific publishing with major international journal and book publishers. Finally, we suggest that publishing with journals and book companies from emerging centers of publishing like the BRICS countries and in Eastern Europe can be also an attractive path for Austrian political science and for similar social science communities in the future.

Keywords: economic impacts of globalization, related disciplines, cultural economics.

\section{Introduction}

In this contribution, we attempt a bibliometric analysis of the evolution of Austrian political science and its presence in global scientific journals and libraries. The analysis is

Journal of Globalization Studies, Vol. 12 No. 2, November 2021 69-102

DOI: $10.30884 / j o g s / 2021.02 .04$ 
based on the study of the publication patterns of 104 senior political scientists associated with Austrian academic institutions since the 1970. ${ }^{1}$ The detailed analysis of the trajectory of this social science community, which hitherto was not really at the center of global knowledge production in the field, generally associated with the major political science institutions in the United States of America, the United Kingdom and a few other countries, ranking top on any common University ranking system, offers many insights into the evolution of global social science in the period of globalization. Our analysis tries to spell out which conditions led to the considerable global presence of the top Austrian social scientists and offers a number of implications for the social science communities around the globe. The implications drawn hold not only for the Austrian political science community but for social scientists from smaller countries and from countries of the semi-periphery and periphery all over the world.

Today, the use of bibliometric comparisons to assess the scientific impact of a political science community is commonplace in the literature (Erne 2007; Hix 2004; Nederhof 2006). There is now a great variety of countries being covered by such studies and the political science communities under such scrutiny include, besides Austria (EnnserJedenastik et al. 2018) the Czech Republic (Kouba et al. 2015); Eastern Europe (Jokic et al. 2019); the Francophone countries (Simard, Cornut 2012); Germany (Chi 2012; Kittel 2009; Pehl 2012; Plümper 2003); Latin America (Basabe-Serrano, Huertas 2018); Norway (Schneider 2009); Poland (Bukowska, Łopaciuk-Gonczaryk 2018); Portugal (Cancela et al. 2014); Quebec, Canada (Cardinal, Bernier 2017); Switzerland (Bernauer, Gilardi 2010); and the United Kingdom (Butler, McAllister 2009).

But these analyses content themselves with the usual bibliometric indicators of social science journal publications, citations, and a few other analytical indices associated with them, like the H-Index (see below). The Austrian case study, mentioned above (EnnserJedenastik et al. 2018), only calculates the Austrian share in political social science and international relations publishing over time. None of these studies, however, hitherto analyzed the question of the global library presence of such a community. Seen from the perspective of smaller countries and the global periphery and semi-periphery, this question is far from trivial, and deserves a lot of future research efforts (see below).

In general, only occasionally international social science journal sever took notice of the development of political science in Austria in general. One of these few exceptions was the analysis published by Pelinka, 1996 in the leading political science journal of the neigh boring country Switzerland. There, the author already found a strong, and what we interpret even alarming dependence of the career patterns of the professors at the political science departments in Austria from the neigh boring "big brother" Germany, a country with the same official language as Austria, and playing such a dominant role in the Eurozone countries (Laski, Podkaminer 2012; Podkaminer 2016). If anything, this dependence of the Austrian Universities from Germany increased ever since. Today, 28 per cent of the 2500 University professors in Austria are Germans. ${ }^{2}$ Even the Frankfurter Allgemeine (FAZ), Germany's leading newspaper, wrote, 'Aus der Internationalisierung wurdeeine Germanisierung' (i.e., internationalization turned into Germanization). ${ }^{3}$ The FAZ writes that this is problematic if Austria's cultural heritage remains underexposed and the academic curricula and the research content changes. One example, the FAZ maintains, relates to contemporary history. Of six academic sites in Austria with a contemporary history program, four are run by German professors. At these institutes, the main areas of research have shifted. An Austrian research focus - 
about Austrofascism, the culture of remembrance of the Shoah and world political neutrality - is kept alive only in Innsbruck and Vienna.

Most available analyses about the general trajectory of political science in Austria concurred with the general conclusions of Pelinka's analysis, published two and a half decades ago: a relatively low degree of internationalization of the discipline in the country (Decker et al. 2018; Heinisch 2004, 2018; König 2010, 2011, 2013).

The aim of the present contribution is to show that Pelinka's call for increased internationalization of the discipline, for many years centered around the niche of the study of the Austrian political system, was put into practice by a considerable and growing number of scholars, especially from the younger generations. An important segment of the profession took up the challenges of prevailing on global science markets, thus re-iterating the results of an earlier extensive bibliometric analysis already published on the subject (Tausch 2016). In a similar vein, Ennser-Jedenastik et al. 2018, based on a bibliometric analysis about Austrian political science using more limited data from the Web of Knowledge came to a parallel positive conclusion, saying that the number of publications of the researchers with an Austrian affiliation in the SSCI (Social Science Citation Index) journals in the categories of political science and international relations is now three- to four-times higher than 20 years ago. At about 0.7 per cent of the worldwide political science research output in 2016, Austria's contribution is even larger than its share of the world's population (about 0.1 per cent) and, more importantly, its share of global GDP (about 0.34 per cent).

These optimistic results about the positive effects of internationalization presented here could have well even motivated us to entitle our article even with the words 'sursum corda' ('lift up your hearts') used during two millennia of Roman Catholic Liturgy. ${ }^{4}$ Our new hard bibliometric data corroborate the general political economy strategy advice of opening up to global markets (OECD 1998).

In a standard fashion, the evidence presented here is of course also based on the count of the number of articles, the numbers of citations, and the H-Index of authors (Bernauer, Gilardi 2010), all evidenced in the most encompassing global science documentation system today, Scopus. ${ }^{5}$ But as an important addition, we apply the relatively new methodology of assessing the global library outreach of each of our analysed 104 authors achieved by their three most widely circulated book and book chapter publications (White et al. 2009; Tausch 2018).

We present ranking data, based on these variables, using well established techniques of parametric indicator construction based on factor analysis (Heshmati, Oh 2006; Heshmati 2003; Kumbhakar et al. 1999; Casu et al. 2004).

We also present some stylized comparisons of our data with the achievements of the respective current political science association presidents in Germany, ${ }^{6}$ Switzerland, ${ }^{7}$ and the United States of America ${ }^{8}$ as simple benchmark indicators of the standards achieved in other countries, and we also compare the Austrians' achievements with those of Elinor Claire Ostrom (1933-2012), who is the single political scientist ever to have won the Nobel Memorial Prize in Economic Sciences (2009). ${ }^{9}$ The methodology of our comparisons are simple, and admittedly even primitive: instead of collecting the data of thousands of political scientists in those countries, we attempt to answer a simple question: Who else than the current President of a Political Science Association represents the prevailing quality standards of political science, widespread in the country? Who else than the single political scientist ever to have been awarded a Nobel Prize might serve as a role model for the global profession? 
and self-reflection, in which political scientists in Austria broadened and deepened their ties to the transnational discipline and started to engage in a debate on their academic relevance, but still hesitated to systematically inquire into the societal relevance of their work (Senn, Eder 2018).

More pessimistic accounts of the trajectory of the discipline in the most periods abound. Decker et al. (2018) reiterated the assessment already published by König 2011, who argued that the discipline appears incapable to adapt its theoretical and methodological instruments in order to deal with pertinent societal problems. König bemoaned the lack in communication and cooperation on the national and international level and the lack of inter-disciplinary qualities. For Decker et al. (2018) this lack in cooperation undermines the generation of major new knowledge surplus, methodological innovation, the development of theories, and ultimately also the ability to inform political decision-making and the public on pivotal societal questions.

Heinisch (2018) arrived at an even darker description,

In many Western and Northern European countries, the establishment of epistemologically based performance criteria and the definition of official standards has shattered the comfortable notion that all departments and all manners of scholarship were roughly equally valid and thus equally good. When infusions of federal money poured into German universities so that some institutions became officially designated 'excellent,' a new standard of relevance was set. In the remaining seemingly 'non-excellent' departments, the professoriate suddenly found itself relegated to the second tier and in some sense rendered less (academically) relevant. Along with their allies in the traditional media, they struck back, accusing the top tier researchers of being interested more in impact metrics and publications in obscure journals than in contributing to national debates about the big questions. The implication is that democracies are falling apart [...], but all that political science can offer is more quations. Critics of the emerging new mainstream are calling this development the assault of economization on the Humboldtian university tradition of erudite and holistic reflection (Heinisch 2018).

But our analysis shows the opposite, and that important segments of political science in Austria - including critics of the Anglo-American science publishing like Ulrich Brand himself (Brand, Kramer 2018) ${ }^{16}$ - did very well on the international markets and that the emancipation from the very straightjackets of publishing in Germany with its own hierarchies and modes of power was one of the key conditions for the sustainable success of Austrian political science in recent years. Emancipate yourself from Germany, and go global could have been the slogan of the most successful members of the profession.

Still somehow supporting the quoted instances of Austrian self-criticism, the international ranking of Austrian political science journals is currently indeed not yet satisfactory. ${ }^{17}$ The ranking of journals which we briefly report here is based on SCImago Journal \& Country Rank, which is a publicly available portal that includes journals and country scientific indicators developed from the information contained in the Scopus database. SCImago is a research group of the Spanish Consejo Superior de Investigaciones Cientificas (CSIC), the University of Granada, the University of Extremadura, the University Carlos III (Madrid) and the University Alcalá de Henares, dedicated to information analysis. ${ }^{18}$ In their rankings, journals can be grouped by subject area (27 major thematic areas), subject category (313 specific subject categories) or by country. Their citation 
data are drawn from over 34,100 titles from more than 5,000 international publishers and country performance metrics from 239 countries worldwide. The SCImago Journal Rank (SJR) indicator was developed by SCImago from the widely known algorithm 'Google PageRank' (Langville, Meyer 2006). The indicator shows the visibility of the journals contained in the Scopus database from 1996 onwards. Working with this freely available on-line global scientific journal ranking service, offered by SCImago, we arrive at the conclusion that among the 503 global political science and international relations journals, the highest ranked Austrian political science journal is 'European Integration - Online Papers' (rank 184), ${ }^{19}$ followed by the 'Oesterreichische Zeitschrift fur Politikwissenschaft - Austrian Political Science Review' (rank 356), ${ }^{20}$ and 'Living Reviews in European Governance' (rank 398). ${ }^{21}$

Our Table 2 now compares the SCImago rankings of the 'Austrian Political Science Review' with the rankings of political science journals from other countries. Not only journals from highly developed Western countries are ranked ahead of the flagship journal of Austrian political science, but also journals from Eastern Europe, the BRICS countries and developing countries, which all did rather well in comparison to the 'Austrian Political Science Review'(journals in the Russian Federation, Brazil, Romania, Chile, Colombia, Croatia, India, Turkey, China, the Czech Republic, Lithuania, Mexico, Philippines, Poland, Singapore, Slovenia, South Korea, Taiwan-China, and Venezuela). They all would offer rich and growing publication opportunities, and no gatekeepers in Germany are needed to foster a future career of an Austrian social scientist.

Table 2

The SCImago Ranking of the Austrian Political Science Review by international comparison: How many journals from other countries are ranked ahead of the Austrian Journal of Political Science

\begin{tabular}{|l|c|}
\hline & $\begin{array}{c}\text { Number of political science journals, ranked ahead of the } \\
\text { Austrian Journal of Political Science }\end{array}$ \\
\hline United Kingdom & 183 \\
\hline United States & 73 \\
\hline Netherlands & 33 \\
\hline Germany & 12 \\
\hline Spain & 7 \\
\hline France & 6 \\
\hline Russian Federation & 5 \\
\hline Brazil & 3 \\
\hline Canada & 3 \\
\hline Romania & 3 \\
\hline Chile & 2 \\
\hline Colombia & 2 \\
\hline Croatia & 2 \\
\hline India & 2 \\
\hline Turkey & 2 \\
\hline Australia & 1 \\
\hline China & 1 \\
\hline Czech Republic & 1 \\
\hline Denmark & 1 \\
\hline Italy & 1 \\
\hline
\end{tabular}




\begin{tabular}{|c|c|}
\hline & \\
\hline Japan & 1 \\
\hline Lithuania & 1 \\
\hline Mexico & 1 \\
\hline Philippines & 1 \\
\hline Poland & 1 \\
\hline Singapore & 1 \\
\hline Slovenia & 1 \\
\hline South Korea & 1 \\
\hline Sweden & 1 \\
\hline Taiwan & 1 \\
\hline Venezuela & 1 \\
\hline
\end{tabular}

\section{Acquiring a Perspective from Earlier Studies on the Subject}

At the outset, we should state that a bibliometric analysis (Braun 1985) of the global library and academic journal presence must not be interpreted as yet another attempt to arrive at a measure of 'academic quality'. As in the hitherto published single and encompassing bibliometric analysis of Austrian political science (Tausch 2016), we are mainly concerned about reaching out to global scientific markets and about the use of publishing opportunities, pure and simple. Tausch (2016) combined OCLC Worldcat data $^{22}$ about global library presence with data about the maximum library outreach achieved by an author in the very divergent scientific cultures of France, ${ }^{23}$ Sweden, ${ }^{24}$ and Japan, ${ }^{25}$ and the library presence of an author in China. ${ }^{26}$ The study also used journal publishing and citation data from Scopus ${ }^{27}$ and EBSCO Host ${ }^{28}$ and compared journal article publications in Spain, Portugal and in Latin America, indexed in Dialnet, ${ }^{29}$ and article publications in Eastern Europe, indexed in CEEOL. ${ }^{30}$ The last three indicators of the study considered the library presence of an author at the library of the European Commission, ${ }^{31}$ the United Nations in New York, ${ }^{32}$ and at the United States Department of Defense, ${ }^{33}$ to weight the assumed international political and strategic significance of the works of an author. In overall terms, the analysis of the global publishing impact of more than 300 political science researchers from Austria and more than 70 senior researchers with 'habilitation ${ }^{34}$ (i.e., roughly equivalent to tenured professors) already revealed a high global outreach of a considerable and growing globalized segment of the Austrian political science research community (Tausch 2016).

\section{Methodology and Data for the Present Article}

Our present analysis now estimates the global impact of the meanwhile 104 senior Austrian political science researchers, associated today or formerly associated with the three departments of political science in Innsbruck, Salzburg and Vienna. They currently or in the past were working at these departments as full or associate professors, or were granted the 'venialegendi' in the course of the habilitation procedure at their respective departments according to Austrian University law (see also, Pelinka 1996). Our sample also contains the current and past presidents of the Austrian Political Science Association. We also cross-checked the entries in our sample with the current staff of the major political science think-tanks of the country (see our Appendix). All scholars with a ' $h a$ bilitation' degree were included in the sample. 
Bernauer and Gilardi (2010) in their bibliometric analysis of the trajectory of Swiss political science relied on the usual methodology combining the number of articles, academic citations and the so-called H-Index in the Web of Knowledge, now offered world-wide by Clarivate Analytics. In the present analysis, we rely on the same benchmark indicators, provided by the even more encompassing data base Scopus.

In a simple and clear-cut way, we also rely here on data provided by the OCLC Worldcat, the world's single and all-encompassing union catalogue of academic libraries around the globe. ${ }^{35}$ Our global market presence indicators for our political science community under investigation thus are:

- Number of articles indexed in Scopus.

- Total number of quotations documented in Scopus.

- H-Index according to Scopus.

- $O C L C$ Worldcat: book with the largest global library presence.

- OCLC Worldcat: book with the second largest global library presence.

- OCLC Worldcat: book with the third largest global library presence.

Both data systems are easy to handle, and in the following Images, we show the results for the Austro-American scholar Paul Felix Lazarsfeld (1901-1976), who played such an important role in the development of Austrian political science after the Second World War as a teacher and initiator of the establishment of modern social scientific political science in Austria at the Institute for Advanced Studies (IHS) in Vienna (Pelinka 1996).

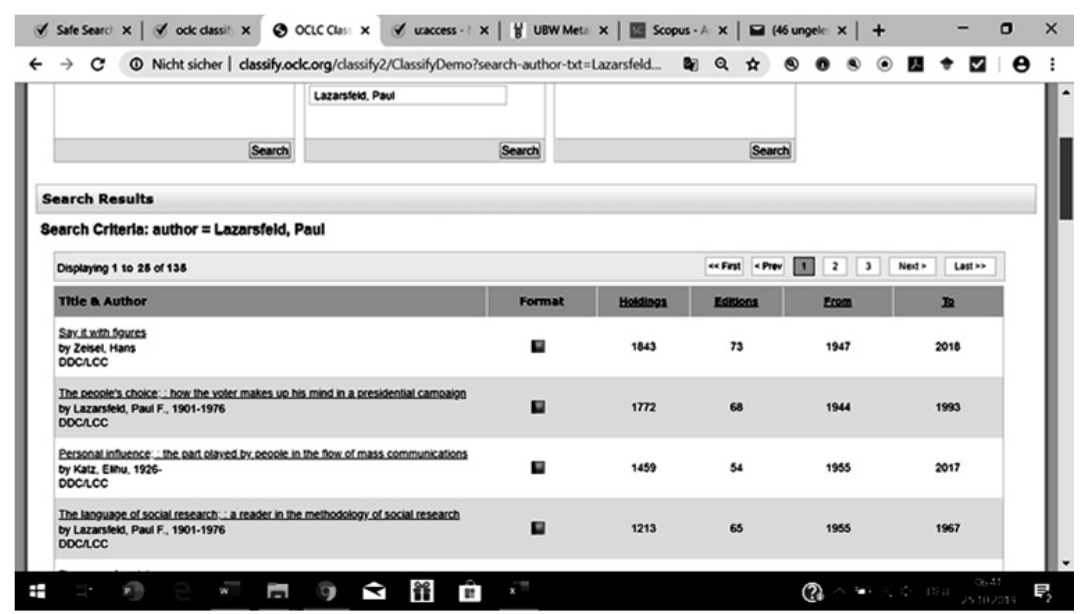

Fig. 1. Global Library presence data for Paul Lazarsfeld from OCLC Classify ${ }^{36}$ 


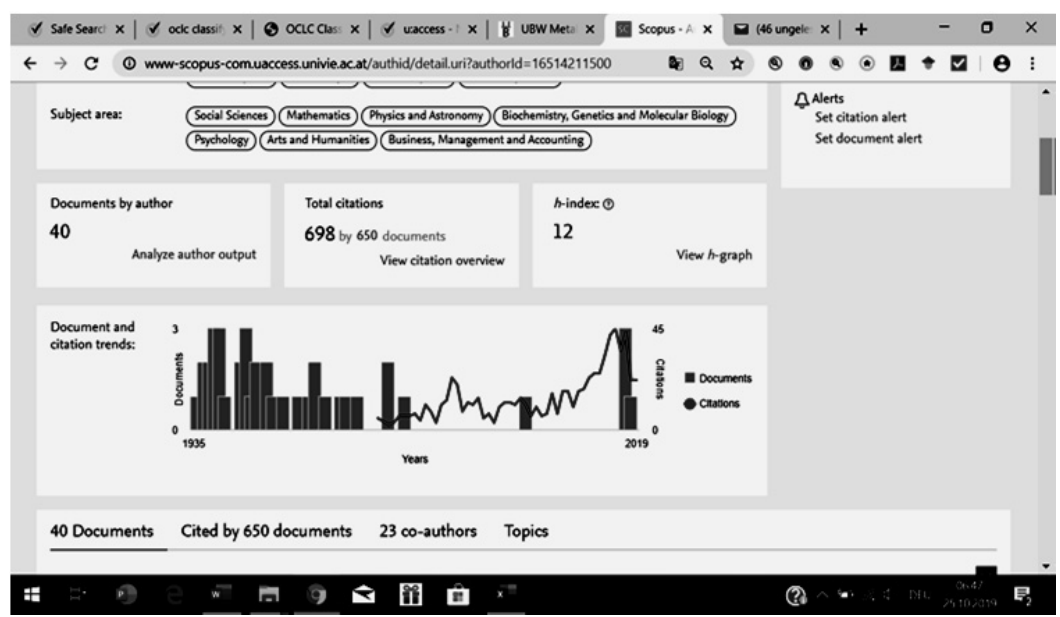

Fig. 2. Global journal presence indicators from Scopus: Paul Lazarsfeld ${ }^{37}$

A few additional remarks about the methodology should follow.

First of all, Bernauer and Gilardi (2010) were correct in emphasizing that the H-Index (Hirsch 2005) measures how many of a given scientist's publications out of his/her total publications $(\mathrm{N})$ have at least $h$ citations, whereas his/her other publications $(\mathrm{N}-\mathrm{h})$ have less than $h$ citations. The H-index of 5 means that a scholar has five publications that have been cited at least five times each. Bernauer and Gilardi underline that the H-Index 'punishes' authors who score a large number of citations with few publications or publish a lot but attract few citations per publication. The H-Index rewards scholars who consistently publish frequently cited works (Ibid.).

In using citation figures, we agree with Bernauer and Gilardi that bibliometric information of the kind we use here is open to questioning. Self-citation not only increases the number of citations, but it also affects how many citations the respective author receives from others. Furthermore, Bernauer and Gilardi (2010) correctly highlighted that the citation process is not necessarily neutral; it can amplify dubious research results and understate solid ones. However, we share with Bernauer and Gilardi the judgement that the number and impact of publications is an important indicator of the international visibility of research activity.

Ideally, our bibliometric investigation should have analyzed the time series data for the performance of the median of the Austrian political science community in comparison with that of other analyzed political science communities. For Austria alone, this would have required the analysis of the time series performance of the currently 500 members of the Austrian Political Science Association. ${ }^{38}$ The competing German political science associations, whose split is beyond the theme of analysis of the present essay (Daase and Deitelhoff 2018; Falter and Wurm 2013; Roß 2013), the DVPW, ${ }^{39}$ and the DGPW ${ }^{40}$ have 1500 members respectively 200 members, while the Swiss Political Science Association, SVPW-ASSP, ${ }^{41}$ has around 600 members ${ }^{42}$ and the American Political Science Association (APSA), founded in 1903, today has 11,000 members in more than 100 countries. For a single researcher it would have been absolutely impossible to perform such a task. Alternatively, we thus had chosen to interpret the succession of the consecutive Presidents of the Austrian political science association and their current global presence in journals and in global libraries as an acceptable first proxy indicator 
of the way, the discipline set itself its standards. Thus, our comparisons with the 'publication culture' of the political science communities in Germany, Switzerland, and the United States of America rested as a first approximation on the analysis of the global journal and library presence of the current Presidents of the respective political science associations in the three countries. In addition, our comparative parameters included the analysis of the journal and global library presence of the first and single winner of a Nobel Prize, the late Nobel Laureate in Economics Elinor Ostrom: ${ }^{43}$

- current German political science president (DVPW) Armin Schäfer - 'Germany 1, 44

- current German political science president (DGPW) Florian Grotz - 'Germany 2, 45

- current Swiss political science president (SVPW) Pascal Sciarini - 'Switzerland' .,46

- current United States political science association (APSA) President Paula D. McClain - 'USA ${ }^{, 47}$.

- Nobel Laureate Elinor Ostrom - 'Nobel Laureate'.

We also compared the global presence of the median of the Austrian political science community in journals and in international libraries to the mentioned scholars from Germany, Switzerland, and the United States of America.

Secondly, we highlight that the reason to include data about the global library presence of scientific works is quite simple and has been explained at length in current bibliometric literature (White et al. 2009; Zuccala, White 2015; Zuccala, Guns 2013; Zuccala et al. 2014, 2015). Library impact measurement techniques are nowadays being called Libcitation measurement techniques, and were developed in the context of the Excellence in Research for Australia program at Sydney University. Libcitation, a term first coined by White et al. 2009 is a measure designed to estimate the global or also the regional presence of authors, universities, research institutes or an entire scientific community on different markets. Whereas traditional citation counts reflect judgments by authors' peers on publications useful to them, Libcitation counts reflect judgments by librarians on the usefulness of publications for their various audiences of readers. The Libcitation measure thus resembles a citation impact measure in discriminating values of publications on a defined ground (White et al. 2009; Tausch 2011). It will be difficult to find a university library from one of the top 100 universities in the world, classified under the Shanghai University Ranking ${ }^{48}$ System, or the SCIMAGO SIR University and Research Institute ranking ${ }^{49}$ based on Scopus indexed publications ${ }^{50}$ which is not a member of the OCLC Woldcat. Virtually all major libraries in Western Europe are also members of the OCLC Worldcat today, for example, 428 in Germany, 1212 in France and 261 in Italy.

Counting the presence of author's or even publishing companies' outputs in Union catalogues is a straightforward methodology to ascertain something like the 'real market weight'. It rewards authors whose books (or other publications) are seen by librarians as having relatively wide appeal. A book's absolute appeal can be determined simply by counting how many libraries hold it.

Zuccala et al. (2015) already established that there is a close correlation between Scopus-Indexed publications and global library presence in Worldcat. Our chosen indicators take into account the all-too-well-known fact that the global audiences in the social sciences are hardly known. Usual attempts at citation-based rankings try to measure the standing of scientists with other members of the science community, and hardly with the global public at large.

At the same time, this way of measurement is much more market-decision based than analyses based on citation patterns, which tell us hardly anything about the geo- 
graphical aspects of the world distribution of knowledge. A librarian or a library community, in addition, has to spend scarce resources on each purchased book, and their decision to buy an academic title, often at the price of $70 \$, 80 \$$, or more, is a real decision to devote scarce resources.

It also makes an important difference whether or not the works of science are available not only in Western Europe, North America and the other industrialized countries, but also around the rest of our globe.

Reaching out to the global publics who might live in Latin America and the Caribbean, Africa, and Asia is an all-important future task of global social science, and people in Anadyr, the easternmost town in Russia, are just as important as readers in Cambridge, Massachusetts, USA, or in Stuttgart, Baden-Württemberg, Germany. Working with the freely available $O C L C$ Worldcat,${ }^{51}$ now integrating the vast majority of academic libraries around the globe (Tausch 2018), we arrive at the startling conclusion that title after title you enter into the system, you arrive at the diagnosis that around 70-80 per cent of all social science titles are held in the libraries in the vicinity of $<3800 \mathrm{kms}$ from Winnipeg, Canada in the geographical center of the highly developed part of the North American continent, 10-20 per cent in the vicinity of $<1750 \mathrm{kms}$ from Brussels, Belgium, and even smaller but relatively constant shares are registered for the social science markets of Australia New Zealand, Southern Africa, and China and East and Southeast Asia.

An analysis of the geographical distribution of the global library holdings of the 'American Political Science Review', the official journal of the most prestigious professional political science association of the world, reveals astonishing and even shocking details about the restricted global distribution of scientific knowledge today. The mentioned journal - symbolic for political science as understood at the leading global Universities and research centers - is available at 920 libraries around the globe. But of these 920 copies, 732 copies (79.6\%) are available in the North American center of the world system, 117 copies (12.7\%) are available in the European center of the world system, 16 copies $(1.7 \%)$ in the Australian sub-center, 3 copies $(0.3 \%)$ in New Zealand, 19 copies (2.1\%) in Southern Africa, and 9 copies (1.0\%) in China and East and Southeast Asia. The rest of the world - the overwhelming vast majority of the geographical space of our globe - has only 24 copies $(2.6 \%)$ at its disposal.

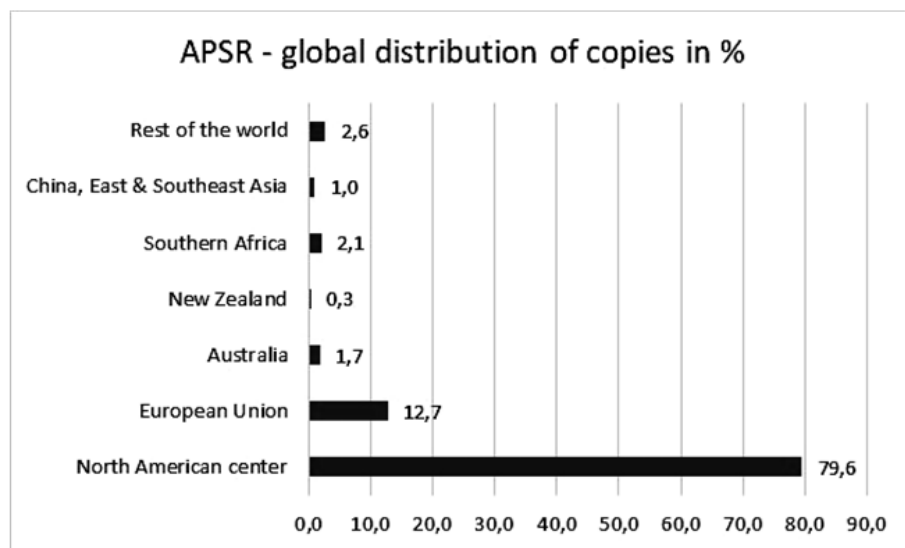

Fig. 3. The global distribution of political science.

The geography of the library holdings of the 'American Political Science Review' 
It has often been argued that in the social sciences and humanities, scholarly publication strategies rather relied on the writing of books and not so much on the publication of research results in peer-reviewed journals (Brand, Kramer 2018). In our analysis, we duly consider this with the ideal indicator now available for such comparisons: OCLC Classify. ${ }^{52}$

Thirdly, we should reflect here on the methods of Index construction. Following the introduction of the meanwhile world-famous Human Development Index and its annual updates in the Human Development Report in recent years (see UNDP 2013) a rich literature on the quantitative measurement of development outcomes has been developed. These outcomes are often multidimensional and each of the dimensions is represented by several indicators with both positive and negative effects on the development outcome. The multidimensionality of the outcome requires the creation of composite indices to have a single measure of performance and also to aggregate the indicators to rank the researchers in one unique way.

Heshmati (2006a, 2006b) highlighted that there are at least two parametric indices employed for computing an index of any development process: the principal component (PC) or factor analysis (FA). PC is frequently used in most analyses. ${ }^{53}$

PC analysis is a multivariate technique used for examining relationships within a set of interrelated quantitative variables. Given a dataset with $\mathrm{J}$ indicators, at most $\mathrm{P}$ principal components can be computed; and each is a linear combination of the original indicators with coefficients equal to the Eigenvectors of the correlation of the covariance matrix. The principal components are sorted according to the descending order of the Eigenvalues, which are equal to the variance of the components. PC analysis is a way to uncover approximate linear dependencies among the indicators. This method gives a least square type solution to the following model:

$$
Y=X B+E
$$

where $Y$ is a $n \times p$ matrix of the centered observed indicators, $X$ is the $n \times j$ matrix of scores of the first $j$ principal components, $B$ is a $j \times p$ matrix of Eigenvectors or factor patterns, $E$ is a $n \times p$ matrix of residuals, $n$ is the number of observations, $p$ is the number of partial indicators, and $j$ the number of indicators of a development process. Unlike in a traditional least-squares estimation method case, where the vertical distance between the observed and the fitted line is minimized, here the sum of the squared residuals is measured as distances from the point to the first principal axis.

As part of the analysis, the Eigenvalues and Eigenvectors are investigated. The Eigenvalues larger than 1.0 are used in the computation of the development process index. The Eigenvalues are declining from the first component to other components. By looking at the Eigenvectors, it becomes evident which indicators form a specific component and the nature of their effects. In each sub-component, an indicator with an Eigenvector exceeding 0.30 or 0.50 is considered statistically as a significant contributor to the principal component.

In practice many researchers use only the first principal component in the computation of a parametric index and in the ranking studied. This method has the disadvantage in that it ignores the information embodied in the remaining indicators. One alternative to account for the information embodied in all principal components with an Eigenvalue larger than one is to use a weighted average PC index. In the aggregation of the principal components, one can use their explained share of the total variance as weights. This method of aggregation will allow the utilization of information from all indicators of an outcome. 
It should be emphasized that the PC method is generally a very useful method to reduce the complexity of the data with multi-dimensions. However, the linear combinations of the different dimensions of interest may not be always easy to interpret.

Our chosen method of factor rotation was Promax factor rotation (Cureton, Mulaik 1975; Finch 2006; Hendrickson, White 1964; Ogasawara 1998). The used statistical software was IBM SPSS Version 24 (Basto, Pereira 2012). Finch (2006), using an item response function conducted a simulation study to compare the performance of two commonly used methods of factor rotation, namely orthogonal (Varimax) and oblique (Promax) to identify the presence of a simple structure. Factor rotation involves a transformation of the initial factor loadings to obtain a greater simple structure without changing the underlying mathematical relationships in the data. Finch suggests the nonlinear factor analysis rotation method as the preferred method. Orthogonal rotations assume the factors are uncorrelated, while the oblique rotations assume the factors are correlated. The former contains the correlation between the factors, while the later measures the relationship between the individual factors and items. Promax takes the rotated matrix provided by Varimax and raises the loadings to powers where the transformed loading values reflect the simple structure better than in the case of Varimax (see Finch 2001). The results from the Finch (2001) simulation study suggest that the two approaches are equally able to recover the underlying factor structure.

\section{Results}

In the following, we will briefly present the research results of our investigation.

The evolutionary aspect of Austrian political science

In a nutshell, we first analyze here how well the successive past Presidents of the Austrian political science association from the year 1970 onwards compare with the standards, set by current Presidents of the political science associations of Germany, Switzerland and the United States of America and the only Nobel Laureate of global political science.

So, in our following graphs, we analyze the (current) global journal and library presence of the successive Presidents of Austrian Political Science with that of the current Presidents of the Political Science Associations in Germany, Switzerland, and the United States of America, and Nobel Laureate Elinor Ostrom. Our images, based on Table 1, are a first indicator for the positive and successful evolution of Austrian political science over the last five decades. The tenure of Rainer Bauböck as President of the Austrian Political Science Association implied a culmination in the internationalization process of the Austrian political science community (Figures 4 to 9). Especially in comparison to the neighboring country Germany, the presence of Bauböck and other presidents of Austrian Political Science Association is noteworthy indeed: 


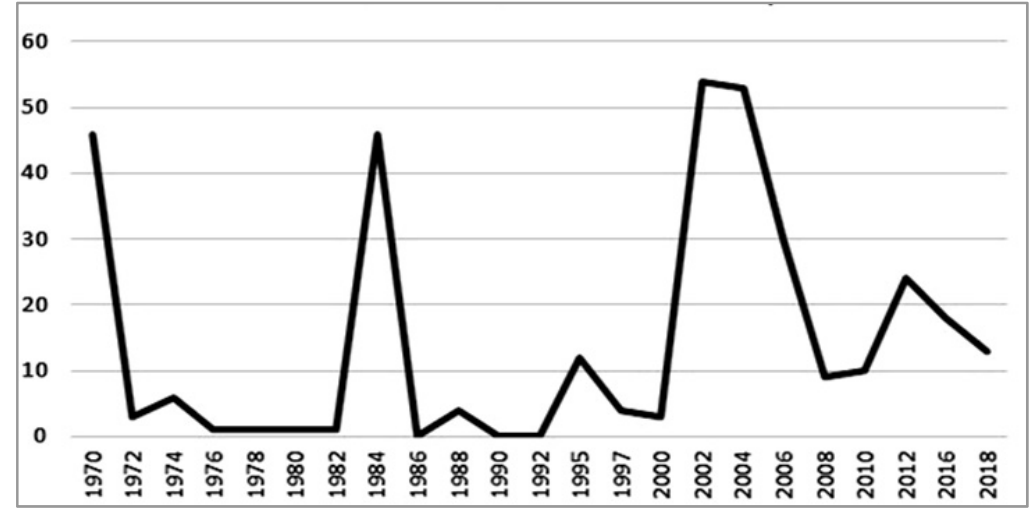

Fig. 4. Number of articles indexed in Scopus

\begin{tabular}{|l|c|c|c|c|c|}
\hline & Germany 1 & Germany 2 & Switzerland & USA & $\begin{array}{c}\text { Nobel } \\
\text { Laureate }\end{array}$ \\
\hline $\begin{array}{l}\text { Number of articles indexed } \\
\text { in Scopus }\end{array}$ & 16 & 13 & 58 & 41 & 204 \\
\hline
\end{tabular}

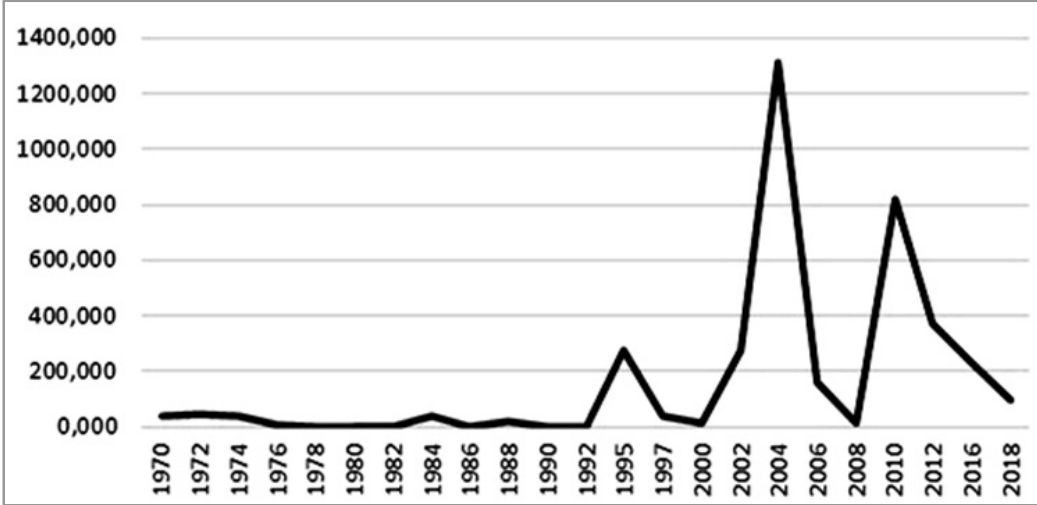

Fig. 5. Total number of quotations documented in Scopus

\begin{tabular}{|l|c|c|c|c|c|}
\hline & Germany 1 & Germany 2 & Switzerland & USA & $\begin{array}{c}\text { Nobel } \\
\text { Laureate }\end{array}$ \\
\hline $\begin{array}{l}\text { Total number of quotations } \\
\text { documented in Scopus }\end{array}$ & 374 & 54 & 802 & 629 & 46,633 \\
\hline
\end{tabular}




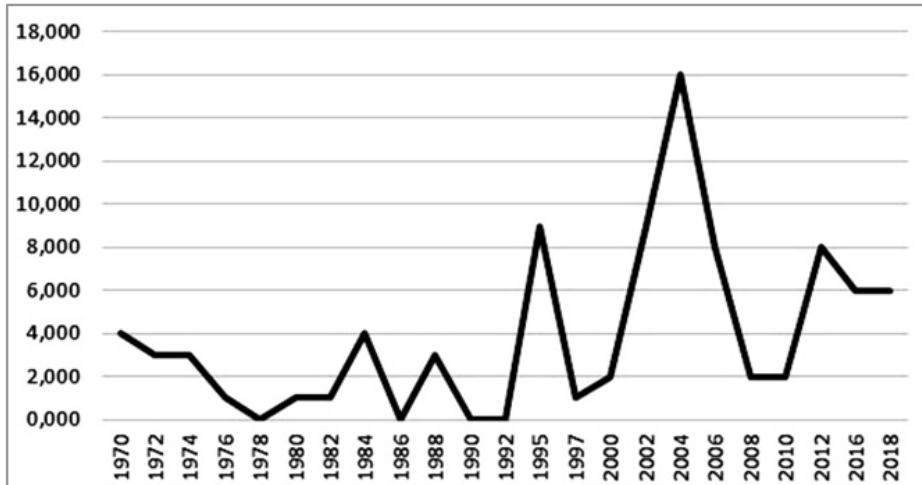

Fig. 6. H-Index according to Scopus

\begin{tabular}{|l|c|c|c|c|c|}
\hline & Germany 1 & Germany 2 & Switzerland & USA & $\begin{array}{c}\text { Nobel } \\
\text { Laureate }\end{array}$ \\
\hline H-Index according to Scopus & 9 & 4 & 17 & 10 & 75 \\
\hline
\end{tabular}

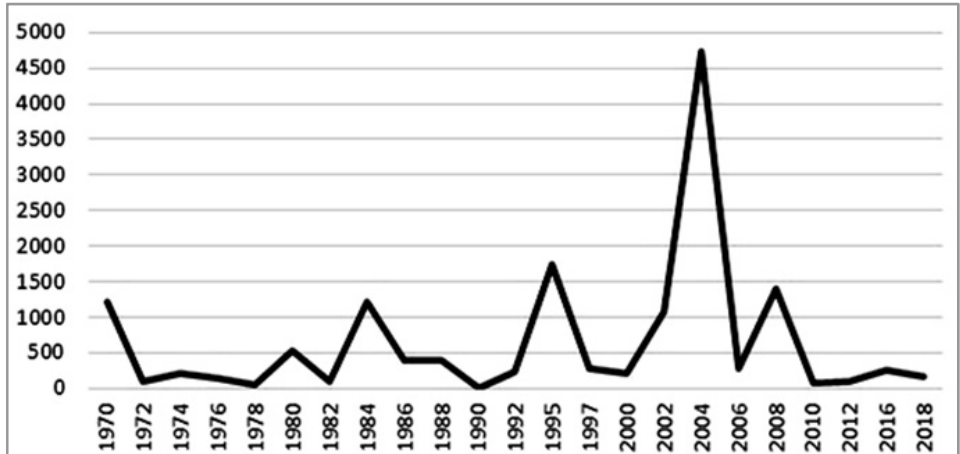

Fig. 7. OCLC Worldcat: book with the largest global library presence

\begin{tabular}{|l|c|c|c|c|c|}
\hline & Germany 1 & Germany 2 & Switzerland & USA & $\begin{array}{c}\text { Nobel } \\
\text { Laureate }\end{array}$ \\
\hline $\begin{array}{l}\text { OCLC Worldcat: book with } \\
\text { the largest global library } \\
\text { presence }\end{array}$ & 67 & 1,432 & 154 & 2,004 & 2,209 \\
\hline
\end{tabular}




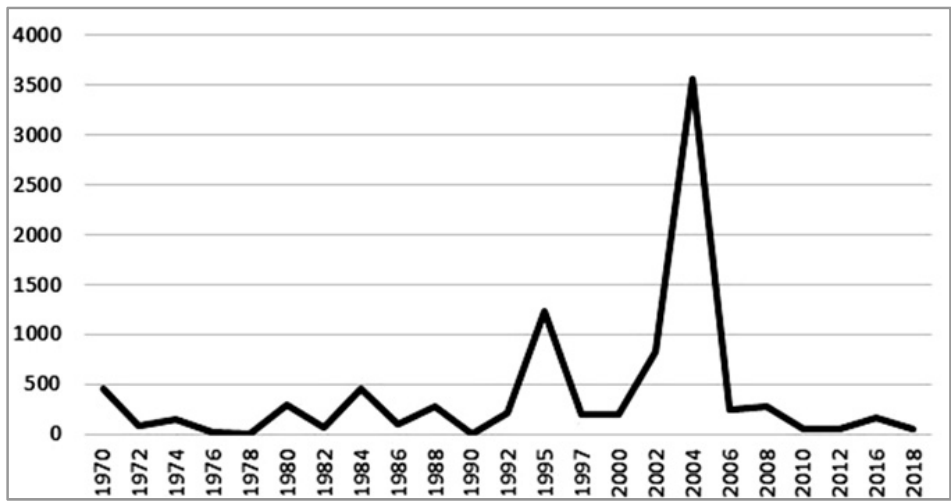

Fig. 8. OCLC Worldcat: book with the second largest global library presence

\begin{tabular}{|l|c|c|c|c|c|}
\hline & Germany 1 & Germany 2 & Switzerland & USA & $\begin{array}{c}\text { Nobel } \\
\text { Laureate }\end{array}$ \\
\hline $\begin{array}{l}\text { OCLC Worldcat: book with } \\
\text { the second largest global } \\
\text { library presence }\end{array}$ & 61 & 296 & 59 & 1,750 & 2,041 \\
\hline
\end{tabular}

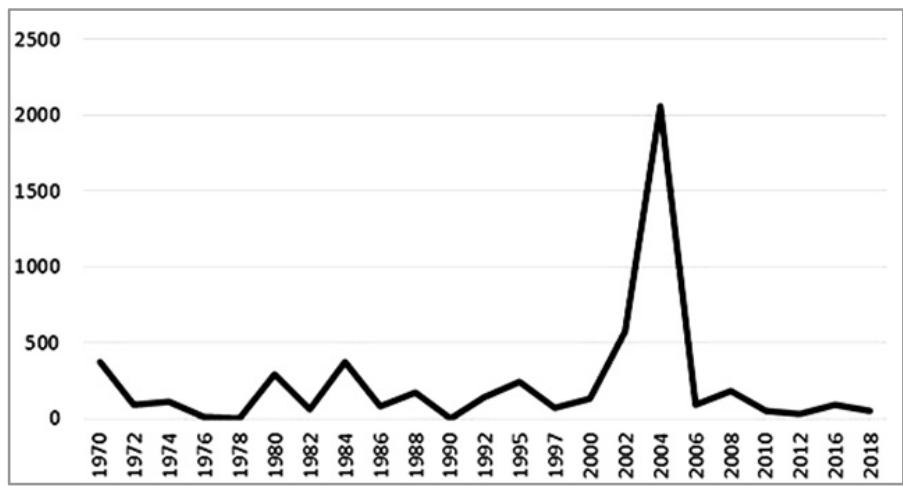

Image 9. OCLC Worldcat: book with the third largest global library presence

\begin{tabular}{|l|c|c|c|c|c|}
\hline & Germany 1 & Germany 2 & Switzerland & USA & $\begin{array}{c}\text { Nobel } \\
\text { Laureate }\end{array}$ \\
\hline $\begin{array}{l}\text { OCLC Worldcat: book with } \\
\text { the third largest global li- } \\
\text { brary presence }\end{array}$ & 56 & 251 & 56 & 320 & 1,960 \\
\hline
\end{tabular}

Even at the risk of oversimplifying our results so far, we can say that the successive Austrian political science presidents compare well with the performance of the current German political science presidents, but that the journal publication performance of the current Swiss political science president rather resembles the American example. 
The global classics of Austrian political science (global library presence is higher than that of the American Political Science Review)

In the following analysis (Box 1) we compare the global library presence of the best placed current classics ${ }^{54}$ of Austrian political science with an undisputed benchmark comparative title - the American Political Science Review. Again, this comparison underlines how globally present Austrian political science has become over the years. The APSR, published continuously since 1906, is the undisputed flagship publication of political science in the United States of America. Since the 'American Political Science Review' today achieves a Libcitation of 920 global libraries, we simply take 920 libraries as a benchmark. Who made it to 920 or more global libraries, wrote a classic:

Box 1. The global classics of Austrian political science with a global library presence greater or equal than the 'American Political Science Review' (920 global libraries) ${ }^{55}$

Bauböck, R. 2006. Migration and Citizenship: Legal Status, Rights and Political Participation (Imiscoe reports). Amsterdam: Amsterdam University Press.

Bauböck, R., and Faist, T. 2010. Diaspora and Transnationalism: Concepts, Theories and Methods (Imiscoe research). Amsterdam: Amsterdam University Press.

Bauböck, R., Perchinig, B., and Sievers, W. 2009. Citizenship Policies in the new Europe (Expanded and updated ed., Imiscoe research). Amsterdam: Amsterdam University Press.

Bunzl, J. 2004. Islam, Judaism, and the Political Role of Religions in the Middle East. Gainesville, FL: University Press of Florida.

Falkner, G. 1998. EU Social Policy in the 1990s: Towards a Corporatist Policy Community (Routledge research in European Public Policy, 6). London: Routledge.

Falkner, G. 2005. Complying with Europe: EU Harmonisation and Soft Law in the Member States (Themes in European Governance). Cambridge, UK: Cambridge University Press.

Gottweis, H. 1998. Governing Molecules: The Discursive Politics of Genetic Engineering in Europe and the United States (Inside Technology). Cambridge, Mass.: MIT Press.

Haerpfer, C. 2002. Democracy and Enlargement in Post-Communist Europe. The Democratisation of the General Public in 15 Central and Eastern European Countries, 1991-1998 (Routledge advances in European Politics). London: Routledge.

Lauber, V. (Ed.). 2012. Switching to Renewable Power: A Framework for the 21st Century. London: Routledge.

Marchart, O. 2007. Post-Foundational Political Thought: Political Difference in Nancy, Lefort, Badiou and Laclau (Taking on the Political). Edinburgh: Edinburgh University Press.

Pelinka, A., Bischof, K., and Stögner, K. 2009. Handbook of Prejudice. Amherst, N. Y.: Cambria Press.

Plasser, F., and Plasser, G. 2002. Global Political Campaigning: A Worldwide Analysis of Campaign Professionals and Their Practices (Praeger series in political communication). Westport, Conn.: Praeger.

Tausch, A. 2009. Titanic 2010?: The European Union and its failed Lisbon Strategy (European political, economic and security issues series). New York: Nova Science.

Tausch, A. 2009. What 1.3 Billion Muslims Really Think: An Answer to a Recent Gallup Study, Based on the World Values Survey. New York: Nova Science.

Thurner, E. 1998. National Socialism and Gypsies in Austria. Tuscaloosa, Ala.: University of Alabama Press. 
Towards a factor analytical parametric global market presence index

In the following, we present the results of our promax factor analysis of the global publishing presence of the Austrian political science community, based on the data of Appendix Table 1. Our Table 3, Table 4, and Table 5 inform about the most important properties of the factor analytical results - the Eigenvalues and the explained variances, the factor loadings of the structure matrix, and the high correlation between the two components. We propose to name the two resulting promax factors 'successful book authors' and 'successful journal article authors'. The correlation between the two factors is +.538 , that is it can be safely assumed that successful journal publishing and successful book publishing go hand in hand, and the explained variance is 28.9 per cent (Table 5).

The total variance explained by our factor analytical model is more than 90 per cent (Table 3). Table 4 reveals that the H-Index, achieved by a scholar in the scientific documentation system Scopus, is the variable with the highest factor loading for the factor 'successful journal article authors'.

Table 3

The Eigenvalues and the explained variance of our factor analytical model

\begin{tabular}{|l|c|c|c|}
\hline & Eigenvalues & $\begin{array}{c}\text { \% of variance } \\
\text { explained }\end{array}$ & $\begin{array}{c}\text { \% of total vari- } \\
\text { ance explained }\end{array}$ \\
\hline successful book authors & 4.185 & 69.751 & 69.751 \\
\hline successful journal article authors & 1.216 & 20.258 & $\mathbf{9 0 . 0 0 9}$ \\
\hline
\end{tabular}

Table 4

The structure matrix loadings of our promax factor analytical model

\begin{tabular}{|l|c|c|}
\hline & $\begin{array}{c}\text { successful book } \\
\text { authors }\end{array}$ & $\begin{array}{c}\text { successful journal } \\
\text { article authors }\end{array}$ \\
\hline Number of articles indexed in Scopus & 0.525 & 0.932 \\
\hline $\begin{array}{l}\text { Total number of quotations documented } \\
\text { in Scopus }\end{array}$ & 0.544 & 0.929 \\
\hline H-Index according to Scopus & 0.478 & 0.973 \\
\hline $\begin{array}{l}\text { OCLC Worldcat: book with the largest global } \\
\text { library presence }\end{array}$ & 0.920 & 0.465 \\
\hline $\begin{array}{l}\text { OCLC Worldcat: book with the second largest } \\
\text { global library presence }\end{array}$ & 0.972 & 0.549 \\
\hline $\begin{array}{l}\text { OCLC Worldcat: book with the third largest } \\
\text { global library presence }\end{array}$ & 0.960 & 0.538 \\
\hline
\end{tabular}

Table 5

The correlations of the components of the promax factor analytical model

\begin{tabular}{|l|c|c|}
\hline \multicolumn{1}{|c|}{ correlation matrix of components } & $\begin{array}{c}\text { successful book } \\
\text { authors }\end{array}$ & $\begin{array}{c}\text { successful journal } \\
\text { article authors }\end{array}$ \\
\hline successful book authors & 1.000 & 0.538 \\
\hline successful journal article authors & 0.538 & 1.000 \\
\hline
\end{tabular}


The rankings according to the parametric global market presence indicators

Appendix Table 2 contains the rankings of the global presence of Austrian political science according to the criteria used in this article. The table is based on standard weighting of the factor scores of the promax factor analytical model by the Eigenvalues of the factors (Tausch, Heshmati 2017). While we underline that the results reproduce over 90 per cent of the variance of the original data based on six indicators, it must be kept in mind that in no way these data represent a qualitative ranking of the 104 scholars.

But following the well-established and conservative quality criterion of scholarly journal publishing, where our respective promax factor combines numbers of articles, citations, and the H-Index, it would emerge that currently the following scholars are the top 20 per cent of the profession in Austria:
1. Prainsack, Barbara.
2. Müller, Wolfgang C.
3. Dür, Andreas.
4. Falkner, Gerda
5. Traweger, Christian.
6. Bauböck, Rainer.
7. Gottweis, Herbert.
8. Haerpfer, Christian.
9. Wagner, Markus.
10. Brand, Ulrich.

\author{
11. Lauber, Volkmar. \\ 12. Campbell, David F. J. \\ 13. Sauer, Birgit. \\ 14. Piattoni, Simona. \\ 15. Helms, Ludger. \\ 16. Spilker, Gabriele. \\ 17. Blauberger, Michael. \\ 18. Kritzinger, Sylvia. \\ 19. Pohoryles, Ronald. \\ 20. Meyer, Thomas
}

\title{
Discussion
}

Thus far, our article already made it sufficiently clear that Austrian political science can be more than proud of its achievements. There is ample evidence of a successful publication strategy based on the international journals, indexed in Scopus and the diffusion of book titles in the global libraries, contained in the OCLC Worldcat by a significant proportion of the Austrian political science community. The following tables are our final rallying cry for a profession which all too often indulged in self-criticism without properly taking into account its achievements under often not very easy and precarious institutional conditions.

Table 6 hypothetically compares the percentile performance of Nobel Laureate Elinor Ostrom, and the American, German and Swiss political science association presidents as if they were members of the Austrian political science community. While Nobel Laureate Ostrom and the current American political science president would be not surprisingly and without any hesitation among the respective top 20 per cent in all respective categories, the current Swiss political science president only in journal publishing would be among the top 20 per cent of his Austrian colleagues, and only one of the two German political science presidents would be among the top 20 per cent of the Austrian colleagues in two of the three dimensions of journal publishing, while the other German political science president is among the best placed 20 per cent of the Austrians in only a single category of book publishing.

Considering the extreme dependency of professorial recruitment of Austrian Universities from the pool of German candidates (more than $1 / 4$, see above), the comparison of the median Austrian political scientist with the performance of the two current German political science presidents is even more striking. While we argue all along in this essay just how important journal publishing is for the profession, and the median Austrian political scientist is still behind the achievements of the current two German political science presidents, the median Austrian political scientist is already outperforming 
the German political science association DVPW current president measured by Libcitation indicators (Table 7).

Table 6

The hypothetical percentile performances of the international political scientists compared to the Austrian political science community according to the six indicators of our study

\begin{tabular}{|l|c|c|c|c|c|c|c|}
\hline & $\begin{array}{c}\text { Number } \\
\text { of articles } \\
\text { indexed } \\
\text { in Scopus }\end{array}$ & $\begin{array}{c}\text { Total } \\
\text { number } \\
\text { of quota- } \\
\text { tions doc- } \\
\text { umented } \\
\text { in Scopus }\end{array}$ & $\begin{array}{c}\text { H-Index } \\
\text { according } \\
\text { to Scopus }\end{array}$ & $\begin{array}{c}\text { OCLC } \\
\text { Worldcat: } \\
\text { book with } \\
\text { the largest } \\
\text { global } \\
\text { library } \\
\text { presence }\end{array}$ & $\begin{array}{c}\text { OCLC } \\
\text { Worldcat: } \\
\text { book with } \\
\text { the second } \\
\text { largest } \\
\text { global } \\
\text { library } \\
\text { presence }\end{array}$ & $\begin{array}{c}\text { OCLC } \\
\text { Worldcat: } \\
\text { book with } \\
\text { the third } \\
\text { largest } \\
\text { global } \\
\text { library } \\
\text { presence }\end{array}$ & $\begin{array}{c}\text { average } \\
\text { perfortile } \\
\text { mance }\end{array}$ \\
\hline $\begin{array}{l}\text { Nobel Laureate } \\
\text { Elinor Ostrom }\end{array}$ & 1.0 & 1.0 & 1.0 & 2.9 & 1.9 & 1.9 & 1.6 \\
\hline $\begin{array}{l}\text { APSA President } \\
\text { Paula D. } \\
\text { McClain }\end{array}$ & 11.4 & 13.3 & 10.5 & 3.8 & 1.9 & 11.4 & 8.7 \\
\hline $\begin{array}{l}\text { current German } \\
\text { political science } \\
\text { president } \\
\text { (DGPW) Florian } \\
\text { Grotz }\end{array}$ & 41.0 & 39.0 & 37.1 & 10.5 & 22.9 & 17.1 & 27.9 \\
\hline $\begin{array}{l}\text { current Swiss } \\
\text { political science } \\
\text { president } \\
\text { (SVPW) Pascal } \\
\text { Sciarini }\end{array}$ & 2.9 & 10.5 & 5.7 & 57.1 & 72.4 & 62.9 & 35.2 \\
\hline $\begin{array}{l}\text { current German } \\
\text { political science } \\
\text { president } \\
\text { (DVPW) Armin } \\
\text { Schäfer }\end{array}$ & 35.2 & 17.1 & 15.2 & 82.9 & 71.4 & 62.9 & 47.5 \\
\hline
\end{tabular}

Table 7

The median Austrian political scientist, absolute performance numbers (column 1) and by comparison with the German political science association presidents, ${ }^{56}$ according to the six criteria used in this study. Austrian median $=100$

\begin{tabular}{|l|c|c|c|}
\hline & $\begin{array}{c}\text { Austrian median } \\
\text { median Austrian } \\
\text { political scientist }\end{array}$ & $\begin{array}{c}\text { Austrian median } \\
\text { performance in \% } \\
\text { of DVPW } \\
\text { President }\end{array}$ & $\begin{array}{c}\text { performance in \% } \\
\text { of DGPW } \\
\text { President }\end{array}$ \\
\hline $\begin{array}{l}\text { Number of articles indexed } \\
\text { in Scopus }\end{array}$ & 8.5 & 53.1 & 65.4 \\
\hline $\begin{array}{l}\text { Total number of quotations } \\
\text { documented in Scopus }\end{array}$ & 29.5 & 7.9 & 54.6 \\
\hline $\begin{array}{l}\text { H-Index according to Sco- } \\
\text { pus }\end{array}$ & 3 & 33.3 & 75.0 \\
\hline
\end{tabular}


Table 7 continued

\begin{tabular}{|l|c|c|c|}
\hline $\begin{array}{l}\text { OCLC Worldcat: book } \\
\text { with the largest global li- } \\
\text { brary presence }\end{array}$ & 188.5 & $\mathbf{2 8 1 . 3}$ & 13.2 \\
\hline $\begin{array}{l}\text { OCLC Worldcat: book } \\
\text { with the second largest } \\
\text { global library presence }\end{array}$ & 96.5 & $\mathbf{1 5 8 . 2}$ & 32.6 \\
\hline $\begin{array}{l}\text { OCLC Worldcat: book } \\
\text { with the third largest glob- } \\
\text { al library presence }\end{array}$ & 69.5 & $\mathbf{1 2 4 . 1}$ & 27.7 \\
\hline
\end{tabular}

We also reach the conclusion that Austrian political science is doing much better than its flagship journal. Working with the geographical criteria used in this article (see above), we can establish ${ }^{57}$ that of the 453 copies of the Austrian Political Science Review (Österreichische Zeitschriftfür Politik wissenschaft), 251 (i.e., 55 \%) are available in North America, and 169 (i.e., 37 \%) are available in the libraries of the European Union. Only 7 per cent are available in the rest of the world. It should be mentioned here by comparison that the German political science flagship journal 'Politische Viertel jahresschrift' is present at 593 global libraries, 460 of these in North America. ${ }^{58}$ But an astonishing number of the Austrian political scientists under scrutiny here (30 of 104, i.e. $28.8 \%$ ) could place their most widely disseminated work at more libraries than the Austrian Political Science Review. Fifteen scholars (14.4\%) even surpassed the global library presence of the Austrian Political Science Review with their second-best work, and five scholars (4.8\%) surpassed the global presence of Austrian political science journal even with their third best placed work.

\section{Some More Comparisons from the Web of Knowledge}

We finally rounded up our Scopus-based analyses with data from the Clarivate Analytics Web of Knowledge. We selected the Social Sciences Citation Index (SSCI), and specified results from the fields of Political Science (POL SCI) and International Relations (IR) ${ }^{59}$ We compared the number of SSCI publications in POL SCI or in IR in 1970-2014 and in 2015 to 2019; and we looked at the world share of the respective political science community in 1970-2014 and in 2015-2019, and we considered the improvements of the most recent five-year period compared to the years 1970-2014. In addition, we analyzed the performance of the respective political science community in relation to the share of global GDP of the respective country. ${ }^{60}$

Austrian political science has now a world share of 0.88 per cent, thus almost tripling its low percentage share of 0.34 per cent of the years 1970-2014. The Austrian political science community could thus improve its hitherto very low global share by a factor of 2.59. The share of Austrian political scientists in global social scientific publishing in SSCI journals is now 2.59 greater than Austria's share in global GDP.

However, Table 8 also informs our readers about the quantitative and qualitative leap forward by the Swiss political science community during the same time period, which now has a global percentage share of 1.87 per cent of all published materials in the field of Political Science and International Relations, indexed in the Social Sciences Citation Index. The Swiss colleagues of the Austrian political scientists still even more forcefully followed the strategy, advocated in this article, and increased their global share in Social Sciences Citation Index relevant publishing by 3.50. The Swiss share in 
the published materials in the field of Political Science and International Relations, indexed in the Social Sciences Citation Index, is now 4.56 times higher than the share of Switzerland in global GDP, thus indicating that over the last years, the small country Switzerland became a global medium power in world-wide political science.

Table 8

Austrian, German and Swiss political science in the Clarivate Analytics Web of Knowledge(Social Sciences Citation Index) - Political Science (POL SCI) and International Relations (IR)

\begin{tabular}{|l|c|c|c|}
\hline & Austria & Germany & Switzerland \\
\hline Number of SSCI publications POL SCI or IR 1970-2014 & 1,935 & 14,528 & 3,035 \\
\hline Number of SSCI publications POL SCI or IR 2015-2019 & 615 & 3,946 & 1,301 \\
\hline $\begin{array}{l}\text { World share of SSCI publications in POL SCI and IR } \\
\text { 1970-2014 in \% }\end{array}$ & 0.34 & 2.56 & 0.53 \\
\hline $\begin{array}{l}\text { World share of SSCI publications in POL SCI and IR } \\
\text { 2015-2019 in \% }\end{array}$ & 0.88 & 5.67 & 1.87 \\
\hline Share of world GDP, 2018 & 0.34 & 3.22 & 0.41 \\
\hline $\begin{array}{l}\text { World share of SSCI publications in POL SCI and IR } \\
\text { 2015-2019 in \% is x-times greater than share of world } \\
\text { GDP, 2018 }\end{array}$ & 2.59 & 1.76 & 4.56 \\
\hline Improvement 2015-2019 to 1970-2014 by a factor of ... & 2.59 & 2.22 & 3.50 \\
\hline
\end{tabular}

The success story of the last five years also implies that the Austrian political scientists' work published between 2015 and 2019 amounted to 24 per cent of the total contributions ever published by Austrian political scientists in the SSCI since 1970. In Switzerland, this share was even 30 per cent, indicating the rapid internationalization of social science in both countries over the last five years.

\section{Beyond 'Dividadura': Political Science Can Offer Good Equations}

Does it make sense then to rely on publication strategies other than good and solid journal publishing and publishing with the main global book publishing companies?

In the current debate about the future of political science in Austria, EnnserJedenastik et al. 2018 also most emphatically made the case for a politically relevant political science, published in the standard fashion of internationally visible high-quality publications. They quote, among others, the work of the economist Thomas Piketty (Piketty 2014).

Brand and Kramer 2018 in their analysis based in the framework of 'critical theory' were generally skeptical about the pressures to follow an internationalization strategy, based on standard publication strategies centered around the international peer-reviewed journals and the major global players in scientific book production. Brand and Kramer (2018) maintain that initially there is nothing against international comparability and English-language publishing, and they recognize that in Austrian political science - at different speeds - an internationally oriented scientific culture is developing.

In his 'siren call' attack on current publication patterns in global social science, Heinisch (2018), spoke about the top tier researchers of the profession of political science being interested more 'in impact metrics and publications in obscure journals than in contributing to national debates about the big questions' (Heinisch 2018). Heinisch's sentence that 'democracies are falling apart [...], but all that political science can offer is more equations' however cannot remain unanswered. Current events in the very 
country Portugal, which is currently practically the only one in Europe which seeks a left-wing answer to the crisis of the Eurozone, have a direct implication not only for European policy-making far beyond the borders of this relatively small country on the outer south-western rim of Europe (Coimbra 2017; de Giorgi, Russo 2018; Lisi 2016, 2017; Martins, Valente 2018; Meirelles 2018; Pinto, Teixera 2019), but incidentally also for the debate on 'crisis and equations', or, if you wish, what a politically and scientifically relevant publication strategy left of the political center can look like in the social sciences today. Such a political science is the aim of Brand and Kramer (2018), in which they spoke about theory, practice and publication strategies. But contemporary Portugal offers a vivid and high-profile example of 'theory and practice' and successful scientific publication strategies. The Portuguese scholar Francisco Louçã (1956), politician and the very founder of the left-wing alliance 'Bloco de Esquerda', ${ }^{61}$ is not only the most important politician of Portugal's far left, but also a renowned econometrician and author of social science. His left-wing alliance 'Bloco de Esquerda' is central in the current success story of Portugal finding out a way of Eurozone austerity, poverty and recession in the wake of the economic crisis of 2008. His work (especially Louçã and Mortagua 2012) is a critique of the current 'dividadura' (word play with the Portuguese words divida, debt and ditadura, dictatorship) suffered by Portugal under Maastricht austerity. Louçã's econometrics of the current crisis in Europe and of the ways out from it were published with leading international publishers in the field of economics, and are part of a growing scientific movement to find an agenda of an 'alternative European project' by means of solid, 'mainstream' quantitative economic analysis, published in leading journals of the discipline. Not only Louçã and associates contributed to this debate, but also the late Austro-Polish political economist Kazimierz Laski (December 15, 1921 - October 20, 2015), who also combined 'critical research' with a standard global publication strategy (Laski, Podkaminer 2012; Louçã 1997, 1998, 2017; Louçã, Ash 2018; Louçã, Mortagua 2012; Podkaminer 2016; Riese 2016).

No word about 'obscure journals' (Heinisch 2018), and 'democracies are falling apart [...], but all that political science can offer is more equations.' On the contrary, Louçã, Laski and the above-mentioned other authors offer equations so that democracy does not fall apart, and they published their findings in the leading journals of the discipline and with the leading book publishers in the field, like Cambridge University Press, Elsevier, and Oxford University Press (see also Araújo, Louçã 2007, 2008; Christopher, Louçã 2001; Freeman, Louçã 2001, 2004; Laski, Podkaminer 2011; Laski, Walther 2015; Louçã 1999, 2001, 2014; Louçã, Terlica 2011; Mata, Louçã 2009; Mendes, Araújo, and Louçã 2003).

Brand and Kramer (2018) wrongly understand the Anglo-Saxon science enterprise as an international mode of power, while it can be shown quite easily that even a great number of scholars, critical of neo-liberal globalization and the current political economy of austerity in Europe were very successful as publishers in this supposedly 'international system of power' (Bornschier 1996; Bornschier, Chase-Dunn 1985; Galbraith 2016, 2016; März 1991; Piketty 2015; Piketty, Zucman 2014; Rothschild 1993, 1993, 2015, just to mention a few).

Brand and Kramer maintain that it remains imperative that

[...] a political science that understands itself as critical does not run after academic fashions and does not submit itself to the dictates of the international 
mainstream and malestream in political and social science (Brand, Kramer 2018: 321, translated by the author).

Many strategic conclusions, reached in the debate about the future of political science in Austria are of importance for the global social science community. In this context, Ennser-Jedenastik et al. 2018, made the important point that placing pre-publication versions of essays with such networks as the Social Science Research Network in New York, ${ }^{62}$ Researchgate, ${ }^{63}$ and Academia.ed ${ }^{64}$ (and the current author adds Ideas/Repec ${ }^{65}$ as another important platform for sharing working papers) is always a good strategy, especially since most internet search engines usually place articles, published with those networks, very high on the result lists.

\section{Conclusions and Strategic Implications}

We argue that Austrian social scientists would do well to consider also publishing in wellestablished journals in the geographical vicinity of Austria or in the BRICS countries. With a growing recruitment of the academic staff of Austrian Universities from the big neighboring country Germany, such a strategic choice also has important cultural and scientific foreign policy implications. Faced with the depressing realities of German economic dominance in the Eurozone (see Laski, Podkaminer 2011; Laski, Walther 2015), German dominance over Austrian Universities is far bigger problem than any 'dangers' 'emanating' from the Anglo-Saxon science enterprise as an international mode of power.

Not only journals from highly developed Western countries are nowadays ranked ahead of the flagship journal of Austrian political science, but also journals from Eastern Europe, the BRICS countries and developing countries, which all did rather well in comparison to the 'Austrian Political Science Review' (journals in the Russian Federation, Brazil, Romania, Chile, Colombia, Croatia, India, Turkey, China, the Czech Republic, Lithuania, Mexico, Philippines, Poland, Singapore, Slovenia, South Korea ...). Thirty years after the fall of the iron curtain, it is depressing to see that of the 104 Austrian political scientists analyzed here, only a handful of them ever published in the high-quality Political Science journals being published in Eastern Europe and being indexed in the Central and Eastern European Online Library CEEOL. ${ }^{66}$ In the hearts and minds of the Austrian political science community, all too often, the Iron Curtain still seems to divide the European continent. The same applies to the many high-quality publishing opportunities, now existing with Russia's Socionauki journals. ${ }^{67}$

If anything, cultural diversity in publishing will be an important task for Austrian political scientists in the future. Compared to the bibliometric study Tausch (2016), the number of Austrian political scientists publishing in French or Spanish still remains very low. These structures will have to change, if Austrian political science wants to continue its successful path.

\section{NOTES}

${ }^{1}$ Mr. Farid Hafez from Salzburg University received his Habilitation degree too recently to be considered here in our final results. Three major figures of Austrian political science, included in our sample, have passed away: Peter Gerlich, 1939-2019; Herbert Gottweis, 1958-2014; and Heinrich Schneider, 1929-2018.

${ }^{2}$ https://science.orf.at/stories/2871360/ and file://C:/Users/Familie\%20Tausch/Downloads/Intpan 5_final.pdf. 
${ }^{3}$ https://www.faz.net/aktuell/wirtschaft/immer-mehr-deutsche-professoren-in-oesterreich-153501 52.html, FAZ, December 26, 2017.

${ }^{4} \mathrm{https} / /$ en.wikipedia.org/wiki/Sursum_corda.

${ }^{5} \mathrm{https}$ ://www.elsevier.com/solutions/scopus; see also de Moya-Anegón, et al., 2007; Falagas, et al., 2008. The author would like to thank the Department of Development Studies at Vienna University for the opportunity to be able to use the Scopus database.

${ }^{6}$ Germany has two competing political science associations: the DVPW, https://www.dvpw.de/, and DGPW, http://www.dgfp.org/.

${ }^{7}$ SVPW, https://www.svpw-assp.ch/home/.

${ }^{8}$ APSA, https://www.apsanet.org/.

${ }^{9} \mathrm{https} / / /$ www.nobelprize.org/prizes/lists/all-prizes-in-economic-sciences/.

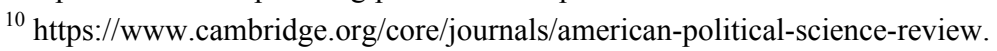

${ }^{11} \mathrm{https}$ ://clarivate.com/webofsciencegroup/solutions/web-of-science/.

${ }^{12} \mathrm{https}: / /$ www.oegpw.at/ueber-uns/information-in-english.

$13 \mathrm{http}$ ://classify.oclc.org/classify $2 /$ ClassifyDemo? search-author-txt $=\% 22 \mathrm{Pelinka} \% 2 \mathrm{C}+\mathrm{Anton} \% 2 \mathrm{C}$ $+1941-\% 22$.

${ }^{14} \mathrm{https}$ //www.worldcat.org/identities/lecn-n80110040/.

${ }^{15}$ https://de.wikipedia.org/wiki/\%C3\%96sterreichische_Gesellschaft_f $\% \mathrm{C} 3 \%$ BCr_Politikwissens chaft and https://www.oegpw.at/fileadmin/user_upload/Vorstand_1970_2019.pdf.

${ }^{16}$ According to $O C L C$ Classify http://classify.oclc.org/classify2/ this work is present at 629 global libraries.

${ }^{17} \mathrm{https}: / /$ www.scimagojr.com/journalrank.php?category=3320. It should be emphasized that in general, science and medical journals rank higher than social science journals. The Austrian Political Science Review, in global terms, is ranked only 22049 of 31971 scientific journals, while the current journal - Social Evolution \& History - is ranked 19392. The world's leading political science journal the American Journal of Political Science - is rank 83 of all global journals.

${ }^{18} \mathrm{https}$ ://www.scimagojr.com/aboutus.php.

${ }^{19} \mathrm{http}$ ://eiop.or.at/eiop/.

${ }^{20} \mathrm{https} / / /$ webapp.uibk.ac.at/ojs/index.php/OEZP.

${ }^{21} \mathrm{http} / / / \mathrm{www}$.europeangovernance-livingreviews.org/.

${ }^{22} \mathrm{https}: / /$ www.worldcat.org/ and http://classify.oclc.org/classify2/.

${ }^{23} \mathrm{https} / /$ ccfr.bnf.fr/portailccfr/jsp/public/index.jsp?failure=\%2Fjsp $\% 2 \mathrm{Fpublic} \% 2 \mathrm{Ffailure.jsp \& su}$ ccess $=\% 2 \mathrm{Fjsp} \% 2 \mathrm{Fpublic} \% 2 \mathrm{Findex}$. jsp \&profile $=$ public .

${ }^{24} \mathrm{http} / / /$ libris.kb.se/form_extended.jsp?f=ext.

${ }^{25}$ https://ci.nii.ac.jp/books/?1=en.

${ }^{26} \mathrm{http}: / /$ opac.calis.edu.cn/simpleSearch.do.

${ }^{27} \mathrm{https}$ ://www.scopus.com/home.uri.

${ }^{28} \mathrm{https} / / /$ www.ebsco.com/products/ebscohost-platform.

${ }^{29} \mathrm{https}: / /$ dialnet.unirioja.es/.

${ }^{30}$ https://www.ceeol.com/.

$31 \mathrm{https}$ ://ec-europa-finder.hosted.exlibrisgroup.com/primo-explore/search?vid=32EUC_VU1\&se arch_scope $=$ default_scope\&query=any, contains, shoah\&lang $=$ en_US\&mode $=$ advanced.

$32 \mathrm{http}: / /$ pmt-eu.hosted.exlibrisgroup.com/primo_library/libweb/action/search.do?mode=Advanced $\& \mathrm{ct}=$ AdvancedSearch $\& \mathrm{frbg}=\& \& \mathrm{fn}=$ search $\&$ ind $=1 \& \overline{\mathrm{ds}} \mathrm{cnt}=0 \& \mathrm{vid}=41 \mathrm{DHL}$ V1\&ct $=$ search $\& \mathrm{srt}=$ rank $\&$ $\mathrm{tab}=$ default_tab\&vl(freeText 0$)=$ shoah\&dum=true\&dstmp $=1564560260712$.

$33 \mathrm{https} / / /$ www.whs.mil/library/ and https://p94008.eos-intl.net/P94008/OPAC/Search/Advanced Search.aspx. To this data, the Pentagon Library catalogue answers an important question for all of 
global social science: whose works are being taken notice of by the military of the world's still leading economic and military power?

${ }^{34} \mathrm{https}$ ://en.wikipedia.org/wiki/Habilitation; see also Brechelmacheret al., 2015.

${ }^{35} \mathrm{https}$ ://www.worldcat.org/ and http://classify.oclc.org/classify2/.

${ }^{36} \mathrm{http} / / /$ classify.oclc.org/classify $2 /$.

${ }^{37} \mathrm{https}$ ://www.elsevier.com/solutions/scopus; see also de Moya-Anegón, et al., 2007; Falagas, et al., 2008. The author would like to thank the Department of Development Studies at Vienna University for the opportunity to be able to use the Scopus database.

${ }^{38} \mathrm{https}: / /$ www.oegpw.at/startseite.

${ }^{39} \mathrm{https}: / /$ www.dvpw.de/.

${ }^{40} \mathrm{http}: / / \mathrm{www} \cdot \mathrm{dgfp} . \mathrm{org} /$.

${ }^{41} \mathrm{https}: / /$ www.svpw-assp.ch/home/

${ }^{42} \mathrm{https}: / / w w w . s v p w-a s s p . c h / d e /$ portrait/.

${ }^{43} \mathrm{https}: / /$ www.nobelprize.org/prizes/economic-sciences/2009/ostrom/biographical/.

${ }^{44} \mathrm{https}: / /$ www.dvpw.de/wir/vorstand/.

${ }^{45} \mathrm{http}: / /$ www.dgfp.org/index.php/vorstand.

${ }^{46} \mathrm{https}: / / \mathrm{www}$. svpw-assp.ch/the-association/standing-committee/.

${ }^{47} \mathrm{http}: / /$ people.duke.edu/ pmcclain/ and https://www.cambridge.org/core/societies/american-poli tical-science-association.

${ }^{48} \mathrm{http}: / /$ www.shanghairanking.com/ARWU2017.html.

${ }^{49} \mathrm{http}: / /$ www.scimagoir.com/.

${ }^{50} \mathrm{https}: / / \mathrm{www}$. elsevier.com/solutions/Scopus.

${ }^{51} \mathrm{https}: / / \mathrm{www}$. worldcat.org/.

${ }^{52} \mathrm{http} / / /$ classify.oclc.org/classify $2 /$.

${ }^{53}$ Principal Component analysis was originally developed by Pearson (1901) and further improved by Hotelling (1933). Heshmati and Oh (2007) used the method for computation of Lisbon Development Strategy Index while Heshmati et al. (2008) used it to study child well-being in high- and middle-income countries.

${ }^{54}$ Monographies and edited titles; no essays to collective volumes, edited by other authors were included in this list. Titles by the author of the current essay are in brackets.

${ }^{55}$ Our list does not include contributions to collective volumes.

${ }^{56}$ Cordoba 3:2? This refers to the historic victory of Austria against Germany at the Football world cup tournament in Cordoba, Argentina, in 1978, which has been a rallying cry for Austrian selfconsciousness ever since. For an English language account, see http://bundesligafanatic.com/2012 0909/germany-v-austria-1978-unravelling-the-shame-of-cordoba/. On the Austrian inferiority complex vis-à-vis Germany, see Jacquette, 2001; Dimitriou, and et al., 2010.

${ }^{57} \mathrm{https}: / /$ www.worldcat.org/advancedsearch.

${ }^{58} \mathrm{https} / / / \mathrm{www}$. worldcat.org/advancedsearch.

${ }^{59} \mathrm{https}: / /$ clarivate.com/webofsciencegroup/solutions/web-of-science/.

${ }^{60} \mathrm{https}: / /$ www.statista.com/.

61 https://ideas.repec.org/e/plo95.html; https://www.parlamento.pt/DeputadoGP/Paginas/Biogra fia.aspx?BID=1651; https://pt.wikipedia.org/wiki/Francisco_Lou $\% \mathrm{C} 3 \% \mathrm{~A} 7 \% \mathrm{C} 3 \% \mathrm{~A} 3$; https://www.hei se.de/tp/features/Portugal-Wahlen-nach-vier-Erfolgsjahren-der-Unbegreiflichkeit-4546542.html.

${ }^{62} \mathrm{https} / / / \mathrm{www} . \mathrm{ssrn} . \mathrm{com} / \mathrm{index} . \mathrm{cfm} / \mathrm{en} /$.

${ }^{63} \mathrm{https}: / /$ www.researchgate.net/.

${ }^{64} \mathrm{https}: / /$ www.academia.edu/.

${ }^{65} \mathrm{https}$ ://ideas.repec.org/. 
${ }^{66} \mathrm{https}: / / \mathrm{www} . c e e o l . c o m /$.

${ }^{67} \mathrm{https}$ ://www.sociostudies.org/.

${ }^{68}$ As we already mentioned briefly above, Mr. Farid Hafez received his Habilitation degree too recently to be considered in the calculation of all the analytical data of our article, like highest and lowest values, the median and also the promax factor analytical model. But for reasons of completeness of this Table, we mention here at least his Scopus and OCLC Classify data in our alphabetical list.

\section{REFERENCES}

Araújo, T., and Louçã, F. 2007. The Geometry of Crashes. A Measure of the Dynamics of Stock Market Crises. Quantitative Finance 7 (1): 63-74.

Araújo, T., and Louçã, F. 2008. The Seismography of Crashes in Financial Markets. Physics Letters A 372 (4): 429-434.

Basabe-Serrano, S., and Huertas, S. 2018. El estado de la investigación en cienciapolíticasobreAmérica Latina. Revista Española de CienciaPolítica 47: 153-170.

Basto, M., and Pereira, J. M. 2012. An IBM SPSS R-menu for ordinal factor analysis. Journal of Statistical Software 46 (4): 1-29.

Bernauer, T., and Gilardi, F. 2010. Publication Output of Swiss Political Science Departments. Swiss Political Science Review 16 (2): 279-303.

Brand, U., and Kramer, H. 2011. Füreinekritische Politikwissenschaft. Anmerkungenzu Thomas Königs Essay 'Das unvollständige Projekt. Best and saufnahme der österreichischen Politikwissenschaft'. ÖZP - Austrian Journal of Political Science 40 (3): $315-323$.

Brand, U., Görg, C., Hirsch, J., and Wissen, M. 2008. Conflicts in Environmental Regulation and the Internationalisation of the State: Contested Terrains. London: Routledge.

Braun, T. et al. 1985. Scientometric Indicators: a 32 Country Comparative Evaluation of Publishing Performance and Citation Impact. Singapore; Philadelphia: World Scientific.

Brechelmacher, A., Park, E., Ates, G., and Campbell, D. F. 2015. The Rocky Road to Tenure-Career Paths in Academia. In Academic Work and Careers in Europe: Trends, Challenges, Perspectives (pp. 13-40). Springer, Cham.

Bukowska, G., and Łopaciuk-Gonczaryk, B. 2018. Publishing Patterns of Polish Authors in Domestic and Foreign Economic Journals. Ekonomista (4): 442-466.

Butler, L., and McAllister, I. 2009. Metrics or Peer Review? Evaluating the 2001 UK Research Assessment Exercise in Political Science. Political Studies Review 7 (1): 3-17.

Cancela, J., Coelho, T. D., and Ruivo, J. P. 2014. Mapping Political Research in Portugal: Scientific Articles in National Academic Journals (2000-2012). European Political Science 13: 327-339.

Cardinal, L., and Bernier, A. 2017. La gouvernance francophone de la Revue canadienne de science politique et la diffusion des connaissances en français, de 1968 à 2015. Canadian Journal of Political Science. Revue canadienne de science politique 50 (1): 57-76.

Casu, B., Girardone, C., and Molyneux, P. 2004. Productivity Change in European Banking: A Comparison of Parametric and Non-Parametric Approaches. Journal of Banking and Finance 28 (10): 2521-2540.

Chi, P. S. 2012. Bibliometric Characteristics of Political Science Research in Germany. Proceedings of the American Society for Information Science and Technology 49 (1): 1-6.

Christopher, F., and Louçã, F. 2001. As Time Goes by: From the Industrial Revolutions to the Information Revolution. London and New York: Oxford University Press. 
Coimbra, E. A. D. 2017. Duasestrelas e doisprojetos de hegemonia: ainfluência do pensamento de Gramsci no Partido dos Trabalhadores (BRA) e no Bloco de Esquerda (POR). URL: https://repositorio.ufsc.br/bitstream/handle/123456789/180418/348911. pdf? sequence $=1$.

Cornut, J., Simard, C., Jegen, M., and Cardinal, L. 2012. L'embauchedans les départements de science politique francophone au Québec et au Canada. Un bilan des années 2000 2010. Politique et Sociétés 31 (3): 87-108.

Cureton, E. E., and Mulaik, S. A. 1975. The Weighted Varimax Rotation and the Promax Rotation. Psychometrika 40 (2): 183-195.

Daase, C., and Deitelhoff, N. 2018. Schissvor'mSchisma. FürepistemischeToleranz in der Politikwissenschaft und den Internationalen Beziehungen. ZIB Zeitschriftfür Internationale Beziehungen 25 (2): 3-5.

De Giorgi, E., and Russo, F. 2018. Portugal: The Unexpected Path of Far Left Parties, from Permanent Opposition to Government Support. In Opposition Parties in European Legislatures (pp. 95-112). Routledge.

de Moya-Anegón, F., Chinchilla-Rodríguez, Z., Vargas-Quesada, B., Corera-Álvarez, E., Muñoz-Fernández, F. J., González-Molina, A., and Herrero-Solana, V. 2007. Coverage analysis of Scopus: A journal metric approach. Scientometrics 73 (1): 53-78.

Decker, P., and Campbell, D. F. J., and Braunstein, J. 2018. Interdisciplinarity as a Source of Relevance in Political Science. ÖZP - Austrian Journal of Political Science 47 (3): 19-32.

Dien, J., Beal, D. J., and Berg P. 2005. Optimizing Principal Components Analysis of Event-Related Potentials: Matrix Type, Factor Loading Weighting, Extraction, and rotations. Clinical Neurophysiology 16: 1808-1825.

Dill, D. D., and Soo, M. 2005. Academic Quality, League Tables, and Public Policy: A CrossNational Analysis of University Ranking Systems. Higher Education 49 (4): 495-533.

Dimitriou, M., Sattlecker, G., and Müller, E. 2010. Der "Mythos Córdoba 1978” im Spiegel der Berichterstattungüber die Fußballeuropameisterschaft 2008. Zwischendiskursiver Rekonstruktion des Vergangenen und kollektiver Identitätsbildung. The "Córdoba Myth" of 1978 as Reflected in the Coverage of the 2008 European Football Championships: Between Discursive Reconstruction of the Past and Collective Identity Development. Sport und Gesellschaft 7 (2): 145-174.

Donohue, J. C. 1974. Understanding Scientific Literatures: A Bibliometric Approach. Cambridge, MIT Press.

Drummond, R., and Wartho, R. 2009. RIMS: The Research Impact Measurement Service at the University of New South Wales. Australian Academic and Research Libraries 40 (2): $76-87$.

Ennser-Jedenastik, L., Meyer, T. M., and Wagner, M. 2018. The Relevance of Empirical Political Science in Austria: Ask Important Questions, Study them Rigorously, and let People Know. Österreichische Zeitschriftfür Politikwissenschaft 47 (3): 33-42.

Erne, R. 2007. On the Use and Abuse of Bibliometric Performance Indicators: A Critique of Hix's 'Global Ranking of Political Science Departments'. European Political Science 6 (3): 306-314.

Falagas, M. E., Pitsouni, E. I., Malietzis, G. A., and Pappas, G. 2008. Comparison of PubMed, Scopus, Web of Science, and Google Scholar: Strengths and Weaknesses. The FASEB journal 22 (2): 338-342.

Falter, J. W., and Wurm, F. W. (Eds.). 2013. Politikwissenschaft in der Bundesrepublik Deutschland: 50 Jahre DVPW. Cham: Springer-Verlag. 
Finch, H. 2006. Comparison of the Performance of Varimax and Promax Rotations: Factor Structure Recovery for Dichotomous Items. Journal of Educational Measurement 43 (1): 39-52.

Freeman, C., and Louçã, F. 2004. Ciclos e crises no capitalismo global. Das revoluçõesindustriais à revolução da informação. Porto: EdiçõesAfrontamento.

Gorsuch, R. L. 1983. Factor Analysis. Hillsdale, N. J.: Erlbaum.

Grinin, L., Korotayev, A., and Tausch, A. 2018. Islamism, Arab Spring, and the future of democracy: World system and world values perspectives (Perspectives on development in the Middle East and North Africa (Mena) region). Cham, Switzerland: Springer.

Heinisch, R. 2004. Political Science between Intellectual Achievement, Critical Discourse and a Search for Relevance: Reflections on the State of the Discipline in Austria and the United States. In Kramer, H. (ed.), Demokratie und Politik. 40 Jahre Politikwissenschaft in Österreich (pp. 71-98). Wien. Peter Lang.

Heinisch, R. 2018. Struggling to Address the 'Big and Burning' Questions: The Opportunities and Perils of (Austrian) Political Science Going Mainstream. Österreichische Zeitschriftfür Politikwissenschaft 47 (3): 71-79.

Hendrickson, A. E., and White, P. O. 1964. Promax: A Quick Method for Rotation to Oblique Simple Structure. British Journal of Statistical Psychology 17 (1): 65-70.

Heshmati A., Tausch, A., and Bajalan, C. 2008. Measurement and Analysis of Child WellBeing in Middle and High Income Countries. European Journal of Comparative Economics 5 (2): 227-286.

Heshmati, A. and Lee, S. 2010. The Relationship between Globalization, Economic Growth and Income Inequality. Journal of Globalization Studies 1 (2): 87-117.

Heshmati, A. 2003. Productivity Growth, Efficiency and Outsourcing in Manufacturing and Service Industries. Journal of Economic Surveys 17 (1): 79-112.

Heshmati, A. 2006a. Measurement of a Multidimensional Index of Globalization. Global Economy Journal 6 (2): Article 1.

Heshmati, A. 2006b. The Relationship between Income Inequality Poverty, and Globalization. In Nissanke, M., and Thorbecke, E. (eds.), The Impact of Globalization on the World's Poor (pp. 59-93). Basinsgtoke and New York: Palgrave Macmillan.

Heshmati, A., and Oh, J. 2006. Alternative Composite Lisbon Development Strategy Indices: A Comparison of EU, USA, Japan and Korea. The European Journal of Comparative Economics 3 (2): 133.

Heshmati, A., and Oh, J-E. 2006. Alternative Composite Lisbon Development Strategy Indices: A Comparison of EU, USA, Japan and Korea. The European Journal of Comparative Economics 3 (2): 133-170.

Hirsch, J. 2005. An Index to Quantify an Individual's Scientific Research Output. Proceedings of the National Academy of Sciences 102 (46): 16569-16572.

Hix, S. 2004. A global ranking of political science departments. Political studies review 2 (3): 293-313.

Hotelling, H. 1933. Analysis of a Complex of Statistical Variables into Principal Components. Journal of Educational Psychology 24: 417-441, 498-520.

Hug, S. E., Ochsner, M., and Daniel, H.-D. 2013. Criteria for Assessing Research Quality in the Humanities: A Delphi Study among Scholars of English Literature, German Literature and Art History. Research Evaluation 22 (5): 369-383.

Jacquette, D. 2001. Fin de siècle Austrian Thought and the Rise of Scientific Philosophy. History of European ideas 27 (3): 307-315. 
Jokić, M., Mervar, A., and Mateljan, S. 2019. The Development of Political Science in Central and Eastern Europe: Bibliometric Perspective, 1996-2013. European Political Science 18 (3): 491-509.

Karlhofer, F., and Plasser, F. 2012. Die Innsbrucker Politikwissenschaft: Konsolidierung und Profilbildung. Österreichische Zeitschriftfür Politikwissenschaft 41 (1): 95-112.

Kittel, B. 2009. Eine Disziplin auf der Suchenach Wissenschaftlichkeit: Entwicklung und Stand der Methoden in der deutschen Politikwissenschaft. Politische Vierteljahresschrift 50 (3): 577-603.

König, T. 2010. Die Geschichte der Disziplin Politikwissenschaftim Verhältniszuösterrichischer Forschungspolitik und gesellschaftlichen Rahmenbedingungen. In Biegelbauer, P. (ed.), Steuerung von Wissenschaft? Die Governance des österreichischen Innovationssystems (pp. 223-257). Innsbruck: Studienverlag.

König, T. 2011. Das unvollständigeProjekt. Bestandsaufnahme der österreichischen Politikwissenschaft. ÖZP - Austrian Journal of Political Science 40 (1): 81-89.

König, T. 2013. Vom Naturrechtzum Behavioralismus und darüberhinaus. Konzeptionelle Grundlagen der Disziplin Politikwissenschaft in Österreich. Österreichische Zeitschriftür Politikwissenschaft 41 (4): 419-438.

Kouba, K., Císař, O., and Navrátil, J. 2015. The Czech Political Science: A Slow March towards Relevance. Political science in Europe at the beginning of the 21st century: 63-85.

Kumbhakar, S. C., Heshmati, A., and Hjalmarsson, L. 1999. Parametric Approaches to Productivity Measurement: A Comparison among Alternative Models. Scandinavian Journal of Economics 101 (3): 405-424.

Langville, A. N., and Meyer, C. D. 2006. Google's Page Rank and Beyond: The Science of Search Engine Rankings. Princeton University Press.

Laski, K., and Podkaminer, L. 2011. Common Monetary Policy with Uncommon Wage Policies: Centrifugal Forces Tearing the Euro Area Apart. Intervention. European Journal of Economics and Economic Policies 8 (1): 21-29.

Laski, K., and Podkaminer, L. 2012. The Basic Paradigms of EU Economic Policy-Making Need to be Changed. Cambridge Journal of Economics 36 (1): 253-270.

Łaski, K., and Walther, H. 2015. Kalecki's Profits Equation after 80 years. In Michat Kalecki in the 21st Century (pp. 131-156). Palgrave Macmillan, London.

Lisi, M. 2016. U-turn: the Portuguese Radical Left from Marginality to Government Support. South European Society and Politics 21 (4): 541-560.

Lisi, M. 2017. There is no Alternative, or is there? The Historic Experiment of the Left-Wing Government in Portugal. LSE European Politics and Policy (EUROPP) Blog. URL: http://eprints.lse.ac.uk/69989/1/blogs.lse.ac.uk-There\%20is\%20no\%20alternative\%20or $\% 20$ is $\% 20$ there $\% 20$ The $\% 20$ historic $\% 20$ experiment $\% 20$ of $\% 20$ the $\% 20$ left-wing $\% 20$ gov ernment $\% 20 \mathrm{in} \% 20$ Portugal.pdf.

Louçã, F. 1997. Turbulence in Economics: An Evolutionary Appraisal of Cycles and Complexity in Historical Processes. Edward Elgar Publishing.

Louçã, F. 1998. The Years of High Econometrics: A Short History of the Generation that Reinvented Economics. Routledge.

Louçã, F. 1999. Nikolai Kondratiev and the Early Consensus and Dissensions about History and Statistics. History of Political Economy 31 (1): 169.

Louçã, F. 2001. Intriguing Pendula: Founding Metaphors in the Analysis of Economic Fluctuations. Cambridge Journal of Economics 25 (1): 25-55. 
Louçã, F. 2014. The Elusive Concept of Innovation for Schumpeter, Marschak and the Early Econometricians. Research Policy 43 (8): 1442-1449.

Louçã, F. 2017. Has the Euro Any Future Under Secular Stagnation? In The Euro and the Crisis (pp. 95-107). Springer, Cham.

Louçã, F., and Ash, M. 2018. Shadow Networks: Financial Disorder and the System that Caused Crisis. Oxford University Press, USA.

Louçã, F., and Mortagua, M. 2012. A Dividadura: Portugal nacrise do Euro. Bertrand Editora.

Louçã, F., and Terlica, S. 2011. The Fellowship of Econometrics: Selection and Diverging Views in the Province of Mathematical Economics, from the 1930s to the 1950s. History of Political Economy 43 (suppl_1): 57-85.

Louca, I., Freeman, C., Louca, F., Louçã, F., and Iseg, F. L. 2001. As Time Goes by: From the Industrial Revolutions to the Information Revolution. Oxford University Press.

Markovits, A. S., and Rosenberger, S. K. (eds.). 2001. Demokratie: mudus und telos: Beïtragefür Anton Pelinka. BöhlauVerlag Wien.

Martins, H., and Valente, J. 2018. Entrevista com Francisco Louçã. Revista Eptic 20 (1): 88-99.

Mata, T., and Louçã, F. 2009. The Solow Residual as a Black Box: Attempts at Integrating Business Cycle and Growth Theories. History of Political Economy 41 (Suppl_1): 334-355.

Meirelles, G. Á. L. D. 2018. Para entender a crisecontemporânea: a experiênciaportuguesacomolição. Revista Katálysis 21 (1): 219-222.

Mendes, R. V., Araújo, T., and Louçã, F. 2003. Reconstructing an Economic Space from a Market Metric. Physica A: Statistical Mechanics and its Applications: 323, 635-650.

Nederhof, A. J. 2006. Bibliometric Monitoring of Research Performance in the Social Sciences and the Humanities: A review. Scientometrics 66 (1): 81-100.

Ogasawara, H. 1998. Standard Errors for Rotation Matrices with an Application to the Promax Solution. British Journal of Mathematical and Statistical Psychology 51 (1): 163-178.

OECD - Organisation for Economic Co-operation and Development. 1998. Open Markets Matter: The Benefits of Trade and Investment Liberalisation. Paris: Organisation for Economic Co-operation and Development.

Pearson, K. 1901. On Lines and Planes of Closest fit to Systems of Points in Space. Philosophical Magazine 6 (2): 559-572.

Pehl, M. 2012. The Study of politics in Germany: A Bibliometric Analysis of Subfields and Methods. European Political Science 11 (1): 54-70.

Pelinka, A. 1995. Fluch und Segen der Normalität. Zur Situation der Politikwissenschaft in Österreich. Österreichische Zeitschriftfür Politikwissenschaft 24 (3): 347-351.

Pelinka, A. 1996. Politikwissenschaft in Österreich. Swiss Political Science Review 2 (4): 1-12.

Pelinka, A. 2018. The Discipline of Political Science: (Re)Positioning between Naïve Objectivity and Self-Destroying Pure Partisanship. ÖZP - Austrian Journal of Political Science 47 (3): 81-88.

Piketty, T. 2014. Capital in the 21st Century, trans. Arthur Goldhammer. Cambridge, MA: Belknap Press: An Imprint of Harvard University Press.

Pinto, A. C., and Teixeira, C. P. 2019. Portugal Before and After the 'Great Recession': A Resilient Democracy? In Political Institutions and Democracy in Portugal (pp. 1-12). Palgrave Macmillan, Cham.

Plümper, T. 2003. Publikationstätigkeit und Rezeptionserfolg der deutschen Politikwissenschaft in internationalen Fachzeitschriften, 1990-2002. Eine bibliometrische Analyse der 
Veröffentlichungs lei stung deutscher politikwissenschaft licher Fachbereiche und Institute. Politische Vierteljahresschrift 44 (4): 529-544.

Podkaminer, L. 2016. Economic Disintegration of the European Union: Not Unavoidable, but Probable. Acta Oeconomica 66 (s1): 49-60.

Riese, M. 2016. Obituary: Kazimierz Laski (1921-2015). European Journal of Economics and Economic Policies: Intervention 13 (3): 265-274.

Roß, B. (ed.). 2013. Migration, Geschlecht und Staatsbürgerschaft: Perspektivenfüreine anti-rassistische und feministische Politik und Politikwissenschaft (Vol. 16). Cham: Springer-Verlag.

Sadlak, J., and Liu, N. C. 2007. The World-Class University and Ranking: Aiming beyond Status. Bucharest, Romania/Shanghai, China/Cluj-Napoca, Romania: Unesco-Cepes.

Sahel, J. A. 2011. Quality Versus Quantity: Assessing Individual Research Performance. Science Translational Medicine 3 (84).

Sauer, B. 2016. Austrian Exceptionalism? Insights from a Huge Department in a Small Country. European Political Science: 332-342.

Schneider, J. W. 2009. An Outline of the Bibliometric Indicator used for PerformanceBased Funding of Research Institutions in Norway. European Political Science 8 (3): 364-378.

SCImago, (n.d.). SJR - SCImago Journal and Country Rank [Portal]. Retrieved Date October 10, 2019. URL: http://www.scimagojr.com.

Senn, M., and Eder, F. 2018. Cui Bono Scientia Politica? A Multi-Dimensional Concept of Relevance and the Case of Political Science in Austria. Österreichische Zeitschriftfür Politikwissenschaft 47 (3): 1-17.

Sieber, J., and Gradmann, S. 2011. How to Best Assess Monographs? Humboldt University Berlin.

Simard, C., and Cornut, J. 2012. La science politique francophone. Défis et trajectoires. Politique et Sociétés 31 (3): 3-8.

Solomon, H. 2008. Challenges to Global Security: Geopolitics and Power in an age of transition (Toda Institute book series on global peace and policy, 2). London: I. B. Tauris.

Solomon, H. 2016. Islamic State and the Coming Global Confrontation. Basinsgtoke: Palgrave Macmillan.

Solomon, H., and Tausch, A. 2020. Islamism, Crisis and Democratization: Implications of the World Values Survey for the Muslim World (Perspectives on development in the Middle East and North Africa (Mena region). Cham: Springer.

Tabachnick, B. G. and Fidell, L. S. 2001. Using Multivariate Statistics. Needham Heights, MA: Allyn and Bacon.

Tausch, A. 2011. On the Global Impact of Selected Social-Policy Publishers in More Than 100 Countries. Journal of Scholarly Publishing 42 (4): 476-513.

Tausch, A. 2015. Die Buchpublikationen der Nobelpreis-Ökonomen und die führenden Buchverlage der Disziplin. Eine bibliometrische Analyse. Bibliotheksdienst 51 (3-4): 339-373.

Tausch, A. 2016. The Global Publishing Trajectory of a European political science community: indices, trends, and implications. [La trayectoria global de publicaciones de una Comunidad Europea de Ciencia Política: índices, tendencias e implicaciones]. Entelequia: Revista Interdisciplinar (Universidad de Cadiz), (19), 261-324. URL: https://re vistaentelequia.wordpress.com/2016/11/26/la-trayectoria-global-de-publicaciones-de-unacomunidad-europea-de-ciencia-politica-indices-tendencias-e-implicaciones/. 
Tausch, A. 2018. The Market Power of Global Scientific Publishing Companies in the Age of Globalization: An Analysis Based on the OCLC Worldcat. Journal of Globalization Studies 9 (2). URL: https://www.sociostudies.org/upload/sociostudies.org/journal/jogs/ 2018 2/063-091.pdf; https://doi.org/10.30884/jogs/2018.02.05.

Tausch, A. 2020. The Political Geography of Shoah Knowledge and Awareness, Estimated from the Analysis of Global Library Catalogues and Wikipedia User Statistics. Jewish Political Studies Review 3.

Tausch, A., and Heshmati, A. 2017. Testing Turkey's Place within the Maps of Global Economic, Political and Social Values. Polish Political Science Review 5 (1): 73-110.

Tausch, A., Heshmati, A., and Karoui, H. 2015. The Political Algebra of Global Value Change. General Models and Implications for the Muslim World. New York: Nova Science Publishers.

Taylor, P., and Braddock, R. 2007. International University Ranking Systems and the Idea of University Excellence. Journal of Higher Education Policy and Management 29 (3): 245-260.

Torres-Salinas, D., Robinson-García, N., and López-Cózar, E. D. 2012. Towards a Book Publishers Citation Reports. First approach using the Book Citation Index. arXiv preprint arXiv:1207.7067.

Torres-Salinas, D., Robinson-García, N., Cabezas-Clavijo, Á., and Jiménez-Contreras, E. 2014. Analyzing the Citation Characteristics of Books: Edited Books, Book Series and Publisher Types in the Book Citation Index. Scientometrics 98 (3): 2113-2127.

Torres-Salinas, D., Robinson-Garcia, N., Miguel Campanario, J., and Delgado López-Cózar, E. 2014. Coverage, Field Specialisation and the Impact of Scientific Publishers Indexed in the Book Citation Index. Online Information Review 38 (1): 24-42.

Torres-Salinas, D., Rodríguez-Sánchez, R., Robinson-García, N., Fdez-Valdivia, J., and García, J. A. 2013. Mapping Citation Patterns of Book Chapters in the Book Citation Index. Journal of Infometrics 7 (2): 412-424.

UNDP - United Nations Development Program. 2013. Human Development Report 2013. The rise of the South: Human Progress in a Diverse World. New York: United Nations Development Program and Oxford University Press.

Usher, A., and Savino, M. 2007. A Global Survey of University Ranking and League Tables. Higher Education in Europe 32 (1): 5-15.

Vinkler, P. 2010. The Evaluation of Research by Scientometric Indicators. Oxford [England]: Chandos Publishing.

Waltman, L., and Schreiber, M. 2013. On the Calculation of Percentile-Based Bibliometric Indicators. Journal of the American Society for Information Science and Technology 64 (2): 372-379.

White, H. D.; Boell, Sebastian K.; Yu, H.; Davis, M.; Wilson, C. S.; Cole, Fletcher T. H. J. 2009. Libcitations: A Measure for Comparative Assessment of Book Publications in the Humanities and Social Sciences. Journal of the American Society for Information Science and Technology, 60 (6): 1083-1096.

Zuccala, A. A., and White, H. D. 2015. Correlating Libcitations and Citations in the Humanities with Worldcat and Scopus Data. In Salah, A. A. et al. (es.), Proceedings of the $15^{\text {th }}$ International Society for Scientometrics and Informetrics (ISSI), Istanbul, Turkey, 29th June to 4th July, 2015 (pp. 305-316). Bogazici University. 
Zuccala, A., and Guns, R. 2013. Comparing Book Citations in Humanities Journals to Library Holdings: Scholarly Use versus Perceived Cultural Benefit. In 14th international conference of the international society for scientometrics and informetrics (pp. 353-360).

Zuccala, A., Guns, R., Cornacchia, R., and Bod, R. 2015. Can we Rank Scholarly Book Publishers? A Bibliometric Experiment with the Field of History. Journal of the Association for Information Science and Technology 66 (7): 1333-1347.

Zuccala, A., Someren, M., and Bellen, M. 201 4. A Machine-Learning Approach to Coding Book Reviews as Quality Indicators: Toward a Theory of Megacitation. Journal of the Association for Information Science and Technology 65 (11): 2248-2260.

\section{Appendix}

Appendix data

\section{Political science in Austria}

1. Austrian Institute for International Affairs. URL: http://www.oiip.ac.at/en/home.html.

2. Austrian Ministry of Defense and Sports (senior staff). URL: http://www.bm lv.gv.at/wissen-forschung/publikationen/person.php?id=5 and http:/www.bmlv.gv.at/wissen-forschung/ publikationen/publikationen.php.

3. Austrian National Defense Academy (senior staff). URL: http://www.bundesheer.at/ organisation/beitraege/lvak/ and http://www.bmlv.gv.at/wissen-forschung/publiationen/publikationen.php.

4. Austrian Study Centre for Peace and Conflict Resolution (ASPR). URL: http://www.aspr. peacecastle.eu/about-us/team/?PHPSESSID=889565cleaffec5a6a50a55bcd235826.

5. Centre for Social Innovation. URL: https://www.zsi.at/en/home.

6. Department of Government, Vienna University. URL: http://staatswissenschaft.univie.ac. at $/$ mitarbeiterinnen/.

7. Department of Political Science, Innsbruck University. URL: http://www.uibk.ac.at/politikwissenschaft/index.html.en.

8. Department of Political Science, Salzburg University. URL: http://www.unisalzburg.at/index.php?id=53599andL $=1$ andnewsid $=4591$ andf $=0$.

9. Department of Political Science, Vienna University. URL: http://politikwissenschaft.univie. ac.at/en/department/.

10. Institute for Advanced Studies (IHS), Vienna, Department of Political Science. URL: http:// www.ihs.ac.at/vienna/About-IHS-3/Stafflist-1.htm.

11. Institute for European Integration Research, Vienna University. URL: http://eif.univie.ac.at/ index-en.php.

12. Institute of Conflict Research (IFK), Vienna. URL: http://www.ikf.ac.at/english/mitarb.htm.

Electronic Appendix available from:

https://www.academia.edu/61786700/FROM THE PERIPHERY TO THE CENTER OF GLOBA L_KNOWLEDGE PRODUCTION A BIBLIOMETRIC ANALY Y'SIS OF THE EVOLUTTON OF A SOCIAL SCIENCE COMMUNITY FROM A SMALL COUNTRY AUSTRIA APPENDIX _Journal_of_Ğlobalization_Studies_Vol_12_No_2_November_2021_3_20_DODI_10_30884_jogs_202 1_02_00 